Florida International University FIU Digital Commons

$11-12-2014$

\title{
Stable Isotope Biogeochemistry of South Florida Coastal Marine Ecosystems
}

Sarah Elise Strand

sstra026@fiu.edu

DOI: $10.25148 /$ etd.FI14110764

Follow this and additional works at: https://digitalcommons.fiu.edu/etd

Part of the Marine Biology Commons, and the Terrestrial and Aquatic Ecology Commons

\section{Recommended Citation}

Strand, Sarah Elise, "Stable Isotope Biogeochemistry of South Florida Coastal Marine Ecosystems" (2014). FIU Electronic Theses and Dissertations. 1737.

https://digitalcommons.fiu.edu/etd/1737

This work is brought to you for free and open access by the University Graduate School at FIU Digital Commons. It has been accepted for inclusion in FIU Electronic Theses and Dissertations by an authorized administrator of FIU Digital Commons. For more information, please contact dcc@fiu.edu. 


\section{FLORIDA INTERNATIONAL UNIVERSITY}

Miami, Florida

\section{STABLE ISOTOPE BIOGEOCHEMISTRY OF SOUTH FLORIDA COASTAL MARINE ECOSYSTEMS}

A thesis submitted in partial fulfillment of

the requirements for the degree of

MASTER OF SCIENCE

in

ENVIRONMENTAL STUDIES

by

Sarah Strand 
To: Interim Dean Michael R. Heithaus

College of Arts and Sciences

This thesis, written by Sarah Strand, and entitled Stable Isotope Biogeochemistry of South Florida Coastal Marine Ecosystems, having been approved in respect to style and intellectual content, is referred to you for judgment.

We have read this thesis and recommend that it be approved.

Jennifer Rehage

Leonard Scinto

William Anderson, Major Professor

Date of Defense: November 12, 2014

The thesis of Sarah Strand is approved.

Interim Dean Michael R. Heithaus

College of Arts and Sciences

Dean Lakshmi N. Reddi

University Graduate School

Florida International University, 2014 
ABSTRACT OF THE THESIS

STABLE ISOTOPE BIOGEOCHEMISTRY OF SOUTH FLORIDA COASTAL MARINE ECOSYSTEMS

\author{
by \\ Sarah Strand \\ Florida International University, 2014 \\ Miami, Florida \\ Professor William Anderson, Major Professor
}

Southeast Florida's continual urban expansion will potentially increase anthropogenic pollution in adjacent coastal marine systems. Furthermore, increased nutrient loads could have detrimental effects on the already threatened Florida Reef Tract. The present study uses a stable isotopic approach to determine the sources and the impact of nutrients on the Florida Reef Tract. $\delta^{13} \mathrm{C}$ and $\delta^{15} \mathrm{~N}$ analysis of macroalgae, sponges, and sediment were analyzed in order to determine nutrient inputs in this region. While $\delta^{13} \mathrm{C}$ data did not display any significant trends spatially, $\delta^{15} \mathrm{~N}$ values of the majority of biota exhibited a strong East to West gradient with more enriched values close to shore. Relative enrichment in $\delta^{15} \mathrm{~N}$ values were measured for sediments sampled along the Florida Reef Tract in comparison to a pristine Marquesas Keys sediment core. The $\delta^{15} \mathrm{~N}$ data also implies that shoreline anthropogenic nutrients have more nutrient loading implications on reefs than major point sources. 


\section{TABLE OF CONTENTS}

CHAPTER

PAGE

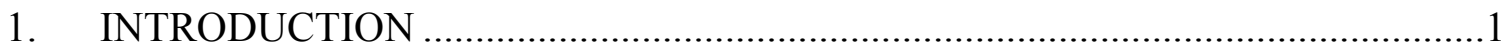

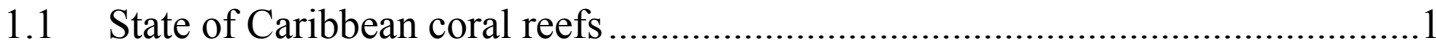

1.2 Condition of the Florida Reef Tract.....................................................................

1.3 Anthropogenic nutrient influences on Florida Reef Tract ...................................

1.4 Role of macroalgae and sponges in coral reef ecosystems ..................................

1.5 Stable isotopes as bioindicators of human inputs ...............................................

1.6 Use of sediment core samples to indicate anthropogenic influence ...................10

1.7 Research questions...................................................................................

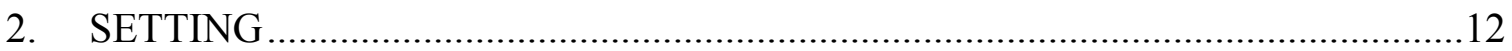

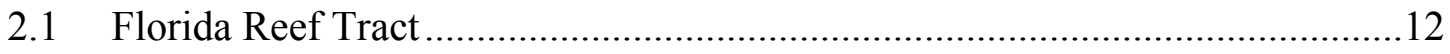

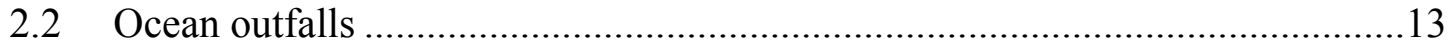

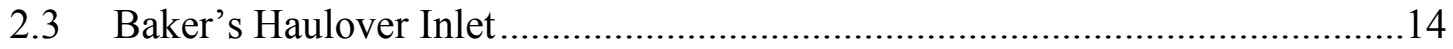

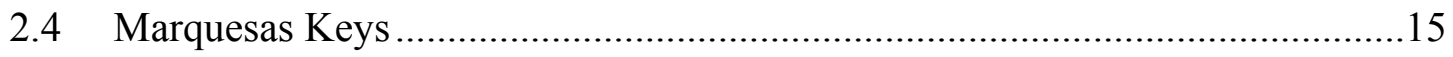

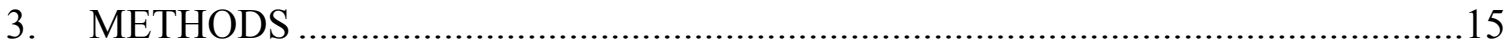

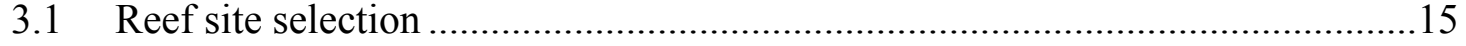

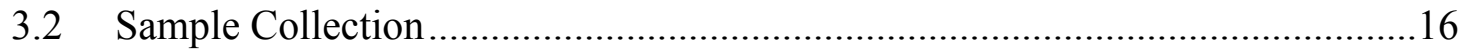

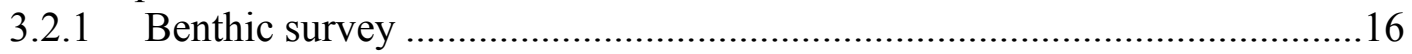

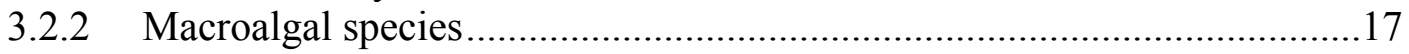

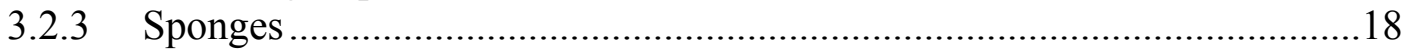

3.3.4 Surface sediment ..........................................................................18

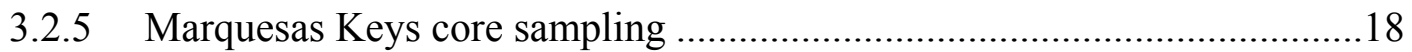

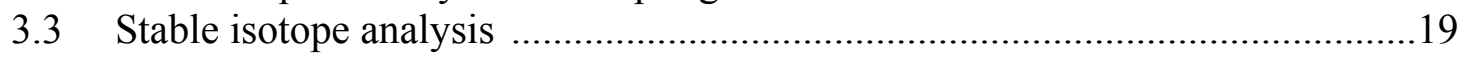

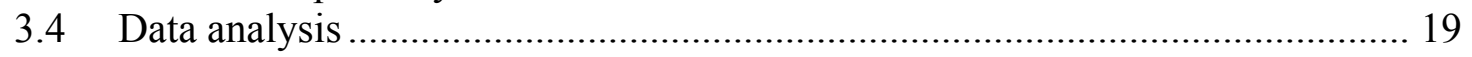

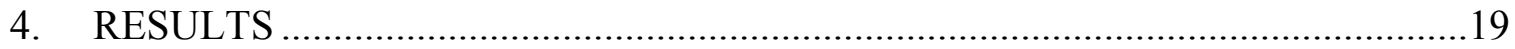

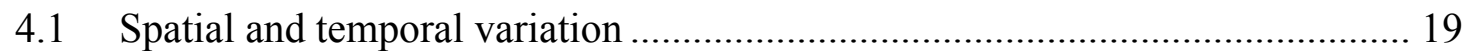

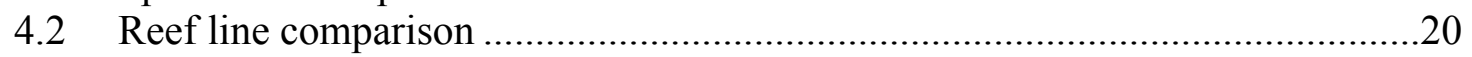

4.3 Variation with respect to distance from inlet and outfalls ................................21

4.4 Sediment core and reef sediment comparison .................................................21

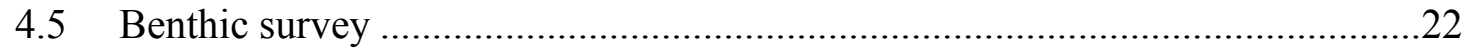

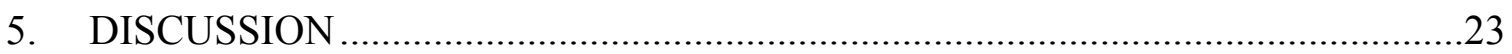

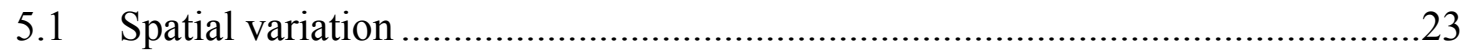

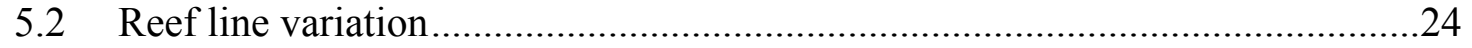

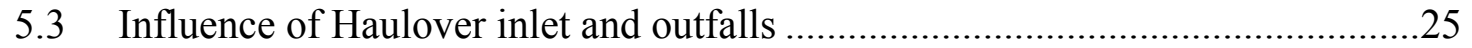

5.4 Sediment core and reef sediment comparison …….....................................2

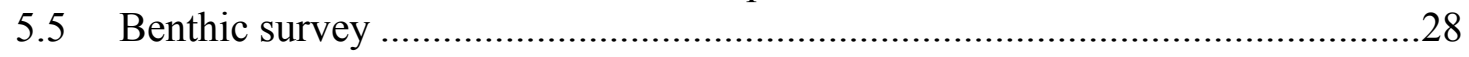

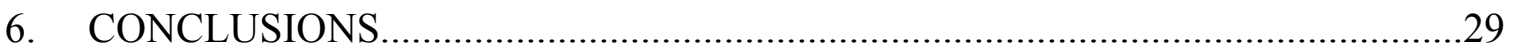


7. WORKS CITED 


\section{LIST OF TABLES}

TABLE

PAGE

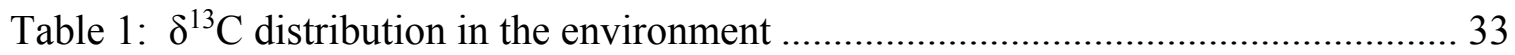

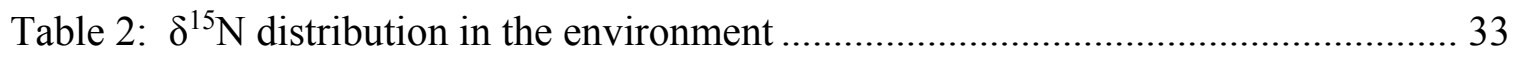

Table 3: RVC benthic survey data for sites recorded (A) ....................................... 34

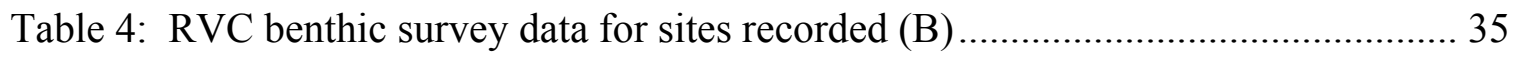

Table 5: RVC benthic survey data for sites recorded (C) ...................................... 36

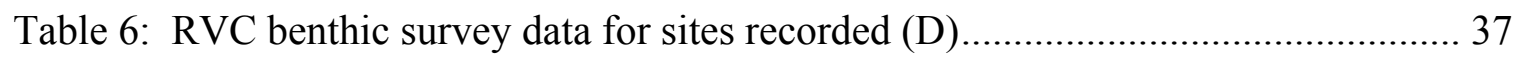

Table 7: Spearman Rank correlation coefficients between $\delta^{15} \mathrm{~N}$ and $\delta^{13} \mathrm{C}$ of Halimeda spp., Dictoyta spp., and sponge and distance from shore, distance from outfall, distance from inlet and depth.....

Table 8: Mean $\delta^{13} \mathrm{C}$ and $\delta^{15} \mathrm{~N}$ values and $\pm \mathrm{SD}$ of all Halimeda spp., Dictoyta spp., and sponge on the first reef line

Table 9: Mean $\delta^{13} \mathrm{C}$ and $\delta^{15} \mathrm{~N}$ values and $\pm \mathrm{SD}$ of all Halimeda spp., Dictoyta spp., and sponge on the second reef line.

Table 10: Mean $\delta^{13} \mathrm{C}$ and $\delta^{15} \mathrm{~N}$ values and \pm SD of all Halimeda spp., Dictoyta spp., and

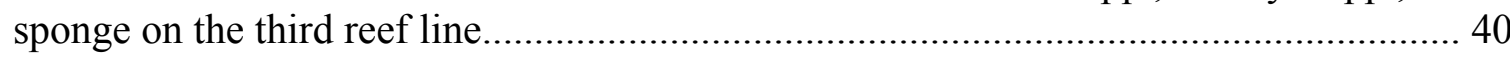

Table 11: Principle Component Analysis of benthic characteristics .............................41

Table 12: Baseline values of $\delta^{13} \mathrm{C}$ and $\delta^{15} \mathrm{~N}$ values for biota in this study ....................41 


\section{LIST OF FIGURES}

FIGURE

PAGE

Figure 1: Conceptual model of bottom up control of nutrient enrichment and the potential trophic cascading in a coral reef ecosystem (McCook 1999) ........................... 42

Figure 2: Continental Southeast Florida Reef Tract (Banks et al., 2008)...................... 43

Figure 3: Florida Reef Tract dive sites (GIS World Imagery layer) ............................44

Figure 4: Marquesas keys map

(http://www.brucechard.com/home/satellitelowerkeyscharts.html).

Figure 5: Mean $\delta^{15} \mathrm{~N}$ values of all three biota groups over the sampling period displaying temporal variability .46

Figure 6: $\delta^{15} \mathrm{~N}$ data of Halimeda spp., Dictoyta spp., and sponge samples collected at the South sites plotted against longitude.

Figure 7: $\delta^{15} \mathrm{~N}$ data of Halimeda spp., Dictoyta spp., and sponge samples collected at the Haulover sites plotted against longitude

Figure 8: $\delta^{15} \mathrm{~N}$ data of Halimeda spp., Dictoyta spp., and sponge samples collected at the South sites plotted against longitude.

Figure 9: Linear regression of $\delta^{15} \mathrm{~N}$ values for Halimeda spp. by distance from shore....49

Figure 10: Linear regression of $\delta^{15} \mathrm{~N}$ values for sponges by distance from shore .50

Figure 11: Mean $\delta^{15} \mathrm{~N}$ of Halimeda spp. across the sampling region 51

Figure 12: Mean $\delta^{15} \mathrm{~N}$ of sponge across the sampling region.

Figure 13: Mean $\delta^{15} \mathrm{~N}$ data of Halimeda spp., Dictoyta spp., and sponge samples collected at all sites along the three reef lines....

Figure 14: Linear regression of $\delta^{15} \mathrm{~N}$ values for sponges by distance from outfall

Figure 15: Linear regression of $\delta^{15} \mathrm{~N}$ values for Dictoyta spp. by distance from Haulover inlet... .55

Figure 16: Comparison of $\delta^{15} \mathrm{~N}$ and $\delta^{13} \mathrm{C}$ data for the North and South sites..... .56 
Figure 17: Marquesas Keys core dated using ${ }^{210} \mathrm{~Pb}$ and Florida Reef Tract sediment

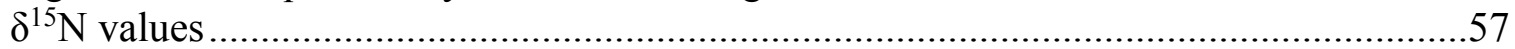

Figure 18: Marquesas Keys core dated using ${ }^{210} \mathrm{~Pb}$ and Florida Reef Tract sediment

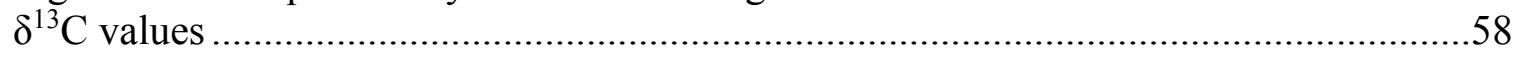

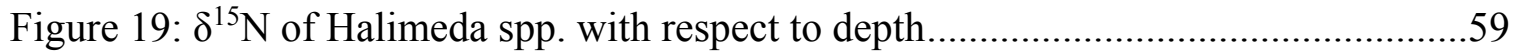

Figure 20: Principle component analysis for site variation with respect to benthic characteristics 


\section{INTRODUCTION}

\subsection{State of Caribbean coral reefs}

As a consequence of negative human influences there has been a regional decline in the health of Caribbean coral reefs over the past few decades (Edinger et al., 2008; Côté et al., 2013; Jackson et al., 2012). Anthropogenic stressors on coral reef ecosystems include rapid population increase, global warming, costal pollution, overfishing, and introduction of invasive species (Barber et al., 2012). Consequently, these stressors have increased coral disease, causing a decrease in overall coral complexity, and have instigated an increase in macroalgal cover (Quinn, 2005). Regionally, coral cover has declined from around $34 \%$ to $16 \%$ and led to an increase in benthic macroalgal cover from $7 \%$ to $23 \%$ in the last thirty years (Jackson et al., 2014).

The Jamaican Caribbean monitoring program has been able to document extreme decreases in reef structure, reef complexity, and biodiversity since the 1980's (Hughes, 1994). The Jamaican reefs have experienced a "phase shift" from a reef-dominated system to a macro algal-dominated ecosystem as a result of both natural and human induced pressures (Côté et al., 2013). The macroalgal phase shift in Jamaica was initiated with the destruction of corals following Hurricane Allen in 1980 and was perpetuated by increased fishing pressures and human waste (Jackson et al., 2014). Increased fishing pressures along the Jamaican reefs have eliminated herbivores that feed on macroalgae exclusively, allowing for macroalgae to grow abundantly as they were lacking natural herbivores (McManus and Polsenberg, 2004). Increased human pollution helped the transition to a macroalgal-dominated system because nutrient enrichment has negative impacts on coral physiology (D’Angelo and Wiedenmann, 2014). Macroalgaes are able 
to opportunistically uptake the excess nutrients and are able to outcompete old and new coral species (Figure 1) (McManus and Polsenberg, 2004). Increased nutrient loading and concentration will increase algal growth when that nutrient is the limiting factor (McCook, 1999). Subsequently macroalgae blooms decrease the complexity of the system, as there is a reduction in benthic coral and sponge cover (Hoegh-Guldberg, 1999). The degradation of Jamaican coral reefs provides an excellent example of how local human activities can severely alter an existing system.

\subsection{Condition of the Florida Reef Tract}

A benthic shift from hard corals to soft corals and macroalgal-dominated reefs has occurred along the Florida Reef Tract (Lamb et al., 2012). The increase in macroalgal cover is likely the result of the geological position of the Florida Reef Tract, which makes it uniquely vulnerable to human pollution (Jackson et al., 2014). The first reef line of the Florida Reef Tract is located within $1.5 \mathrm{~km}$ of southeast Florida's highly urbanized shoreline (Collier et al., 2008). The coastal region of southeast Florida contains around one third of Florida's total population of 16 million people (U.S. Census Bureau, 2010). Urbanization in coastal southeast Florida is expected to continue to increase as the population in this area is predicted to double by the year 2050 (Risk et al., 2009).

Subsequently, there could be a potential increase in the anthropogenic nutrients affecting the Florida Reef Tract.

A report published by the Global Coral Reef Monitoring Network (GCRMN) (2014) on the state of the Caribbean Coral reefs calls the present day Florida Reef Tract a "worse-case scenario" for conservation efforts. The report states that Florida Reef Tract is a "worst-case scenario" because of the rapid population growth in the region and the 
lack of adequate regulations. Because of its proximity to shore, the reef tract is also susceptible to a spectrum of damage that can come from diverse factors such as the recent findings that the components of sunscreen cause coral bleaching and stimulate viral infections (Danovaro et al., 2008). The report by GCRMN cites the vulnerability of the reef tract because of seasonal hurricanes, which serve as a natural stressor to the reefs. The GCRMN report emphasizes the importance of monitoring anthropogenic impacts on the Florida Reef Tract in order to preserve these ecosystems.

\subsection{Anthropogenic nutrient influences on Florida Reef Tract}

The present study focuses on understanding the impacts of increased anthropogenic nutrients on the northern portion of the Florida Reef Tract. Previous studies have evaluated the contribution of anthropogenic point and nonpoint sources to Southeast Florida coastal marine ecosystems. More specifically, research has been conducted to ascertain if human inputs are the cause of macroalgal blooms on the Florida Reef Tract (Anderson et al., 2012). Over the past decade Palm Beach and Broward counties have seen significant blooms of Caulerpa brachypus (Lapointe et al. 2006). The increased occurrence of macroalgal blooms along the Florida Reef Tract has made research on the effects of human nutrient loading by human sources imperative.

Natural processes such as upwelling and sediment resuspension by storms can also be the cause of nutrient enrichment in an ecosystem. Upwellings are a wind driven process that pushes cool nutrient rich water to the top of the water column (Coolier et al., 2006). These conditions are ideal for macro and microalgae growth, as these species are able to dominate in these nutrient enriched environments. In South Florida upwellings occur during the summer season and are more prominent in the months of July through 
August (LaPointe et al., 2005; LaPointe et al., 2010). Another natural process that can cause nutrient enrichment along reefs is sediment resuspension. When natural occurrences such as tsunamis or hurricanes bring wind and wave action that disturbs the sediment, there is a redistribution nutrients contained within them (Fanning et al., 1982). The sediment is resuspended in the water column, which liberates nutrients and allows them to be dispersed in areas in which there was not an abundance of nutrients prior (Coolier et al., 2008). Therefore, it is important to understand all the sources of nutrients into a marine system and utilize methods that can distinguish between natural and anthropogenic nutrient enrichment (Swart, 2010).

Studies have focused on attributing nutrient enrichment to point sources of pollution because nonpoint pollution is hard to ascertain, as there are often multiple unidentifiable sources contributing to the pollution profile. In South Florida the two largest point sources of pollution are ocean outfalls and inlets. Since the beginning of the twentieth-century, humans have exploited oceans as natural sinks and have used oceans as a way to dispose of urban and industrial sector wastewater (Grace, 2009). Primarily the ocean is utilized as a sink through the disposal of wastewater through ocean outfalls. Ocean outfalls are constructed underground and outflow effluent, secondary-treated sewage, directly into the ocean through pipes (USEPA, 2006). Ocean outfalls increase nutrient loading and concentrations on the reefs and can have detrimental effects on the local flora and fauna communities as they will have to adapt to these new levels of enriched nutrients.

Inlets are another major source of anthropogenic nutrients. A study by Futch et al. (2010) in Broward County suggests that inlets may be a more significant source of 
contamination to coastal ecosystems than sewage outfalls. Samples taken in this study showed a trend of having higher potential sewage impact and fecal bacterial indicator from the Port Everglades Inlet than the Broward ocean outfall. The increased sewage impact and fecal bacterial indicator at the inlet are likely a result of nutrient enrichment in the intercoastal from the use of septic tanks and terrestrial runoff. A similar trend was also shown in a study done at Boynton Inlet by Casey et al. (2007). Point sources of human nutrients such as inlets and outfalls can contribute significant nutrient loading that can alter the benthic composition and relationship between species in marine ecosystems.

\subsection{Role of macroalgae and sponges in coral reef ecosystems}

Calcified macroalgae play a vital role in a coral reef ecosystem as they reinforce the skeletal structure of corals, fill in gaps between corals, reduce erosion on reefs, and help connect dead and living coral (Nelson, 2009). Calcified macroalgae also are ecosystem engineers because they provide a habitat for invertebrates and have been shown to increase biodiversity. As primary producers all macroalgaes are the base of the food chain and therefore have the ability greatly impact other trophic levels. Calcareous macroalgae abundance is said to be one of the strongest indicators of coral reef health (Steneck et al., 2011).

Sponges also play a significant role in the benthic composition of Caribbean coral reefs. Sponges are the most diverse and abundant group in the Caribbean coral reef benthic species (Diaz and Rützler, 2001). These species can greatly impact a coral reef system as they serve as nitrifiers, bioeroders, reef structure contributors, and as food sources (Diaz and Rützler, 2001). Sponge nitrification has shown to be a dominant source of dissolved inorganic nitrogen (DIN). Nitrogen fixed by sponges is generally 
relseased as $\mathrm{NH}_{4}{ }^{+}$(Gibson, 2011). A majority of sponges receive carbon through the respiration of dissolved organic carbon (DOC) (Gibson, 2011). As a result of their water filtering capability, sponges play an important role in the dynamics of carbon and other nutrients in the water column (Ward-Paige et al., 2005).

Although benthic macroalgae and sponges are vital for the health of the overall ecosystem, increased biomass of these species can be detrimental to corals. An increase of anthropogenic nutrients can promote the exponential growth of macroalgae and sponges, which have the potential to overgrow and outcompete corals and their aggregates (McManus and Polsenberg, 2004; Diaz-Pulido and McCook, 2005). Macroalgae and sponge species have the ability to become toxic and induce coral disease by disrupting essential microbial communities associated with corals (Jackson et al., 2014). In extreme cases this can cause a "phase shift" as previously mentioned (HoeghGuldberg, 1999). Consequently, "phase shifts" could have cascading effects on biodiversity, trophic levels, and human economical and social values in South Florida (Knowlton and Jackson, 2008).

\subsection{Stable isotopes use as bioindicators of human inputs}

One of the obstacles of studying nutrient loading in marine systems is the difficulty in pinpointing impacts of anthropogenic sources versus natural occurrences. Often concentrations of DIN are below the detectable limit and are continuously changing both periodically and seasonally (Yamamuro et al., 2003). Stable isotopes of nitrogen and carbon represent a time-integrated measure of assimilated nutrients rather than a potentially fluctuating value (Yamamuro et al., 2003). In natural abundance, earth carbon and nitrogen each have two stable isotopes. The lighter isotopes ${ }^{12} \mathrm{C}$ and ${ }^{15} \mathrm{~N}$ are 
found in more abundance (about $99 \%$ and $99.6 \%$ ), while the heavier isotopes ${ }^{13} \mathrm{C}$ and ${ }^{14} \mathrm{~N}$ and more rare (about 1\% and $0.4 \%$ ) (Peterson and Fry, 1987). Stable isotopic ratios of the heavy to light isotope change through chemical and biological processes, therefore, there is a wide variation of isotopic values across different species and sources (Peterson and Fry, 1987) (Table 1 and Table 2).

A stable isotopic approach has been utilized in studies that quantified the impact of human nutrient inputs using macroalgal species, sponges, and sediment located adjacent to inlets and ocean outfalls (Candida, 2005; Costanza et al., 2001; Hoch et al., 1995; Jacob et al., 2005; Lamb et al., 2012; Lapointe et al., McClelland and Valiela, 1998; 2004; Risk et al., 2009; Savage, 2004; Sweeny et al., 1980; Tucker et al., 1999). Isotopic values are expressed in $\delta^{1}$ values, which evaluate the ratio of heavy to light isotopes in a specific sample. Studies that have utilized an isotopic approach have sampled sediment, macroalgae, and sponges adjacent to outfalls and inlets and then have compared them to background values. The $\delta^{15} \mathrm{~N}$ and $\delta^{13} \mathrm{C}$ have been shown to be effective bioindicators of human derived waste and nutrients in marine ecosystems (Benson et al., 2008; Costanzo et al. 2001; McClelland et al., 1997; McClelland and Valiela, 1998).

Treated wastewater will be isotopically enriched in the heavy isotope of nitrogen (8-12\%) relative to baseline DIN $\delta^{15} \mathrm{~N}$ values of macroalgaes (0-6\%) (USEPA, 2002). The enrichment is the result of natural microbial processes in tertiary sewage treatment

\footnotetext{
${ }^{1} \delta \mathrm{X}=\left[\left(\mathrm{R}_{\text {sample }} / \mathrm{R}_{\text {standard }}\right)-1\right] \mathrm{X} 1000$, where $\mathrm{X}$ is $13 \mathrm{C}$ or $15 \mathrm{~N}$ and $\mathrm{R}$ is the corresponding ratio of heavy to light isotope ${ }^{13} \mathrm{C} /{ }^{12} \mathrm{C},{ }^{15} \mathrm{~N} /{ }^{14} \mathrm{~N}$ and standard reference material is VDPB for carbon and $\mathrm{N}_{2}$ (AIR) for nitrogen (Peterson and Fry, 1987).
} 
plants. In these processes fractionation of ${ }^{15} \mathrm{~N}$ occurs and ${ }^{14} \mathrm{~N}$ is selectively utilized, which then yields ${ }^{15} \mathrm{~N}$-enriched wastewater (Lapointe et al., 2005; Savage, 2005). Plants preferentially incorporate the lighter isotope and therefore marine plants will typically be more depleted in ${ }^{15} \mathrm{~N}$ than its sources of nitrate (Anderson and Fourqueran, 2003). Although there are multiple processes that can lead to enrichment in $\delta^{15} \mathrm{~N}$ values (denitrification and nitrification), relatively enriched $\delta^{15} \mathrm{~N}(>\sim 8 \%)$ marine organisms are often attributed to terrestrial nutrient inputs (Swart et al., 2013; Anderson et al., 2011). Carbon isotopic measurement aids in understanding carbon cycling in marine systems (Fourquerean et al., 2005). Changes in productivity and the isotopic composition of seawater dissolved inorganic carbon (DIC) can cause variability in the ratio of ${ }^{13} \mathrm{C} /{ }^{12} \mathrm{C}$ spatially and temporarily (Anderson and Fourqurean, 2003). Carbon isotope ratios in plants are regulated through the process of photosynthesis and fixation of $\mathrm{CO}_{2}($ Anderson and Fourqurean, 2003). Marine organic carbon is typically more enriched in ${ }^{13} \mathrm{C}$ than terrestrial organic carbon because organisms incorporate dissolved $\mathrm{CO}_{2}$ versus atmospheric $\mathrm{CO}_{2}$ (Smith and Epstein, 1971). Values for atmospheric $\mathrm{CO}_{2}$ are more depleted in the heavy isotope (-8\%), while dissolved $\mathrm{CO}_{2}$ is relatively enriched in the heavy isotope ( $0 \%$ ) (Peterson and Fry, 1987). Therefore, $\delta^{13} \mathrm{C}$ signature of marine organisms will be depleted relative to baseline values if they are influenced by anthropogenic sources (Swart et al., 2013).

There have been multiple studies done in South Florida that have successfully attributed nutrient enrichment to anthropogenic sources. A Lapointe et al. (2004) study in the Florida Keys found a $\delta^{15} \mathrm{~N}$ enrichment of sea grasses and algae species that were close to shore. The Lapointe et al. (2004) study was able to conclude that wastewater 
inputs had significant negative impacts on sea grass beds and coral reef abundance. Enrichment of sea grasses and algae species was easily quantified because the nutrient enriched wastewater was being discharged directly off shore into these communities. Lapointe et al. (2004) was also able to find a link between eutrophication and harmful algal blooms with the increase of ammonia levels created from both wastewater disposal and agriculture runoff. Multiple studies in South Florida have challenged Lapointe et al. (2004) conclusion as deep-water nitrate ranges from +4 to $+6 \%$ (Lamb et al., 2012; Swart et al., 2005; Swart et al., 2013). Therefore, there is much contention in the region on what level of enrichment is acceptable to attribute to wastewater influence.

Another study by Lapointe et al. (2005) along the Florida Reef Tract Deerfield Beach and Jupiter found a significant enrichment in $\delta^{15} \mathrm{~N}$ in the shallow reef sites $(<10$ $m)$. The measured enrichment factor was attributed to their proximity to anthropogenic nutrient sources. The 2005 study measured a $\delta^{15} \mathrm{~N}$ isotope signature of macroalgae at a site adjacent to Boca Raton outfall was $+8.5 \%$, which indicates an influence of wastewater effluent. Measured $\delta^{15} \mathrm{~N}$ values of algae sampled next to the outfall were significantly different from algae samples found at sites not influenced by significant sources of human nutrients. Lapointe et al. (2005) stated that macroalgae $\delta^{15} \mathrm{~N}$ values as low as $+4.5 \%$ could be considered to be sewage influence.

A study by Swart et al. (2013) in Biscayne Bay, a coastal lagoon adjacent the to the Florida Reef Tract, aimed to attribute anthropogenic and natural sources of nitrogen into marine systems. Swart et al. (2013) found a strong relative enrichment of $\delta^{15} \mathrm{~N}$ values for algae, sea grasses, and particular organic matter the closer the species was to land-sea border. They called this phenomenon the East to West correlation as these organisms 
became more depleted as distance to terrestrial sources increased. Agricultural runoff, effluent from a wastewater treatment plant in the area, landfill leakage, and septic tank usage are cited by the researchers as the probably sources of nitrate in to the coastal lagoon. Swart et al. (2013) also predicted a decreased flux of DIN along the Florida Reef Tract, and therefore decreased enrichment in $\delta^{15} \mathrm{~N}$ biota, due to open nature of the Florida Reef Tract compared to the enclosed Biscayne Bay.

There have also been studies in South Florida that did not find relationships with respect to isotopic enrichment and distance to anthropogenic sources. For example, a study by Lamb et al. (2012), which sampled along the Upper Keys portion of the Florida Reef Tract, did not establish any spatial trends for $\delta^{15} \mathrm{~N}$ and $\delta^{13} \mathrm{C}$ values of macroalgaes and sponges. Lamb et al. (2012) attributed differences in $\delta^{15} \mathrm{~N}$ values to fractionation during assimilation of nitrate. Similarly a study by Anderson et al. (2011) along the Broward County portion of the Florida Reef Tract did not observe a sewage influence near wastewater outfalls and major inlets. Researchers in Anderson et al. (2011) suggest that a transect design adjacent to major point sources of anthropogenic nutrients could be better indicator of isotopic changes over a spatial gradient.

\subsection{Use of sediment core samples to indicate anthropogenic influence}

Sediment coring can provide insight of the recent past ( $>100$ years) of paleoenvironment and paleoecosystem change data because of the natural stratification process overtime (Wachnicka et al., 2013). In South Florida $\delta^{13} \mathrm{C}$ and $\delta^{15} \mathrm{~N}$ analysis of sediment core samples have been utilized to indicate historical shifts associated with anthropogenic influence (Brenner et al., 1999; Wachnicka et al., 2013). In the present study we aim to stable $\delta^{13} \mathrm{C}$ and $\delta^{15} \mathrm{~N}$ to understand how a limited human impacted 
marine system looks isotopically. The Marquesas Keys samples provide a baseline for the comparison of the samples found along the Florida Reef Tract, which are highly susceptible to many sources of anthropogenic point and nonpoint inputs. The isotopic values provide insight on natural occurrences that have caused shifts in the Marquesas Keys marine system.

\subsection{Research questions}

The thematic focus of this project revolves around understanding how anthropogenic sources of pollution impact coastal marine ecosystems. To better comprehend the role of human inputs on the Florida Reef Tract, this study aimed to answer several questions:

1) Are transects an effective study design when using stable isotopes as bioindcators of anthropogenic sources?

2) Are there $\delta^{13} \mathrm{C}$ and $\delta^{15} \mathrm{~N}$ trends for biota positioned close to shore?

3) Are there latitudinal isotopic variations along the reef tract?

4) Are the inner, middle, and outer reef complex isotopically different?

5) Do $\delta^{13} \mathrm{C}$ and $\delta^{15} \mathrm{~N}$ values of biota uptake an anthropogenic signal close to Baker's Haulover inlet and the Hollywood and Miami-Dade North outfalls?

6) What biotic and abiotic components affect isotopic values along the reef tract?

7) How does a highly human influenced marine system compare to a "pristine" system isotopically? 
8) How do the $\delta^{13} \mathrm{C}$ and $\delta^{15} \mathrm{~N}$ values of biota measured in this study compare to other reports in similar regions?

\section{SETTING}

\subsection{Florida Reef Tract}

The present study evaluates the Continental Southeast portion of the Florida Reef Tract running $125 \mathrm{~km}$ from south Miami-Dade to West Palm Beach (Banks et al., 2008, Coolier et al., 2008) (Fig. 2). The reef tract contains an early Holocene shelf edge, midshelf reefs and limestone ridges that extends along the coast of Southeast Florida (Banks et al., 2008). The reef ridge complex is composed of an inner, middle, and outer ridge. The ridges run parallel to each other with sandy sediment patches between them.

Sampled sites had an average live coral cover percentage of $10.3 \% \pm 8.9$, and an average temperature of $26.2^{\circ} \mathrm{C} \pm 1.2$ across the sampling months. The depth of the sites ranged from $7.0 \mathrm{~m}$ at the most shallow first line reef site and $19.5 \mathrm{~m}$ at the deepest sampled site along the third reef line. The Miami-Dade reef tract has the shallowest reefs that are increasingly more vulnerable to winter cold fronts than northern sites (Banks et al., 2008).

Coastal circulation along the Florida Reef Tract is affected by the Florida current. The Florida current primarily flows north across the Florida shelf and is portion of the Gulf Stream that reverses flow to return to the Straits of Florida before moving northeast toward Europe (Lee and Mayer, 1977). Average current velocity $2 \mathrm{~km}$ off shore is around $2.5 \mathrm{~m} / \mathrm{s}^{-1}$, with lowest average monthly velocity in the month of November $(1.0$ $\left.\mathrm{m} / \mathrm{s}^{-1}\right)$. 


\subsection{Ocean outfalls}

In the state of Florida there are four management options for disposing of municipal wastewater: ocean outfalls, deep injection wells, traditional reuse and groundwater recharge (USEPA, 2006). The majority of Florida wastewater is removed through the use of ocean outfalls and deep injection wells (USEPA, 2006). A 2002 study at the Miami-Dade County Wastewater Treatment Plant, measured a total 450 million liters per day (mld) of wastewater was discharged through the Miami Dade Central outfall, 420 mld through deep injection wells, 2 mld through traditional reuse, and no use of groundwater recharge treatment. It is important to note that the wastewater in the United States that is being input into ocean is not raw sewage, in the traditional sense, but effluent. Effluent is the term used to describe diluted secondarily-treated wastewater that meets the standards of basic disinfection with chlorine (USEPA, 2002).

There are a total of six municipal wastewater treatment facilities (WWTF) in South Florida's counties of West Palm, Broward, and Miami-Dade. Two WWTF outfalls were located next to sampling sites in this study (Fig. 3). The first ocean outfall is the Hollywood Outfall (26’01'04'N; 80'05'04'W), located $3048 \mathrm{~m}$ from shore with a $28.3 \mathrm{~m}$ discharge depth. The Miami-Dade North Outfall $\left(25^{\prime} 55^{\prime} 48^{\prime} \mathrm{N} ; 80^{\prime} 05^{\prime} 04^{\prime \prime} \mathrm{W}\right)$ is located $3566 \mathrm{~m}$ away and discharges at $32.9 \mathrm{~m}$. The Hollywood outfall exports less wastewater from the outfall a day averaging 16 mld while the Miami-Dade North outfall averages 420 mld for Miami-Dade North (USEPA, 2006).

If operating correctly the USEPA (2006) states that effluent discharge should not have a significant negative impact on the marine ecosystem. USEPA sites that there will be no negative affects because effluent has a density roughly equal to freshwater. 
Therefore, effluent will rise to the surface and homogenously mix with the surrounding salt water and become increasingly diluted. If the ocean is stratified then the effluent will reach equilibrium at depths lower than the surface level and ocean currents will be able to move the effluent effectively, which would help further dilute the wastewater. On average the mixing process takes place in a $400 \mathrm{~m}$ "mixing zone", at which full dilution should take place (USEPA, 2006). The exception would be in shallow seas, as the effluent will not be able to successfully reach full dilution.

\subsection{Baker's Haulover Inlet}

Baker's Haulover Inlet (25'53'59’N; 80'07'26’W) is constructed inlet approximately $90 \mathrm{~m}$ wide and $5 \mathrm{~m}$ deep (Lin and Sasso, 2001) (Fig. 3). Baker's Haulover is the most northern inlet with access to Biscayne Bay. There is a high level of tourism and recreation use of the inlet and the current running in and out of the inlet mouth can range from 4 to 6 knots (Lin and Sasso, 2001). In a study by Futch et al. (2009), a site that was influenced by both the Hillsboro Inlet and Broward Outfall had lower virus prevalence than those stations influenced by the Port Everglades Inlet, alone and showed a similar prevalence to those stations influenced only by the Hollywood outfall. Increased virus prevalence at Port Everglades is likely attributable to the relative differences in activity between the Hillsboro and Port Everglades Inlets, with Port Everglades being more utilized. The study by Futch et al. (2009) displays the importance of measuring anthropogenic influences of inlets. 


\subsection{Marquesas Keys}

The Marquesas Keys are an uninhabited group of 14 islands located $27.8 \mathrm{~km}$ west of Key West, FL, USA (Phillips, 1959) (Fig. 4). The Marquesas Keys are 6 km in diameter and are located in the Florida Keys National Marine Sanctuary as a part of the Key West National Wildlife Refuge (Bressett et al., 2010). The islands are predominately inhabited by mangrove species. Mooney Harbor, the only lagoon for the islands, is located on the northeastern most point of the island, which includes shallow (on average less than $2 \mathrm{~m}$ water depth) sea grass beds (Bresett et al., 2010). Marquesas Keys sediment has a sand, silt, and clay mix with a mean grain size of $6.2 \pm 0.9$ on the Krumbien phi scale (Briggs and Richardson, 1997). The most prominent benthic groups found at these islands are Halimeda spp., Dictoyta spp., and Thalassia spp. (Phillips, 1959). The Marquesas Keys island group has historically had little human influence and has rarely been sampled for scientific analysis. Because of its isolation from anthropogenic impact and the "pristine" nature of this area it was used as a reference control in the present study.

\section{METHODS}

\subsection{Reef site selection}

Sampling sites were selected from three different regions along the Florida Reef Tract separated as; North (north of the Broward county line), Haulover (adjacent to Bakers Haulover inlet), and South (South of Bay Harbor Islands) (Fig. 3). The range of latitude from the most northern site to the most southern site is from $26^{\circ} 01^{\prime} 10^{\prime \prime} \mathrm{N}$ to $25^{\circ} 47^{\prime} 07^{\prime \prime} \mathrm{N}$. The North sites are located adjacent to the Hollywood Outfall (Fig. 3). Dives in this region sites ranged from 420 to $5,881 \mathrm{~m}$ from the outfall. Haulover sites 
were located next to two major point sources of pollution; Miami-Dade North outfall and Baker's Haulover Inlet (Fig. 3). Dives sites ranged from 470 to 5,000 $\mathrm{m}$ from the outfall and 493 to $5,942 \mathrm{~m}$ from the inlet. The South region dive sites were not adjacent to a significant point source of pollution. On average the South sites were located the furthest from shore, while the North sites were the closest. The average distance from shore of the first reef line for the South sites was 2,110 m while the North and Haulover sites averaged 1,459 and $1,956 \mathrm{~m}$, respectfully.

Each of these three regions was broken into 18 transects that were randomly selected on a given field day with a total of 54 potential transects. Each transect included the inner, middle, and outer reef ridge. Dives were then conducted on each reef line along the randomly selected transects from June 2013 through March 2014. A total of 22 separate transects were sampled, but not all three reef lines were sampled along some transects (Fig. 3).

\subsection{Sample collection and analysis}

\subsubsection{Benthic survey}

Benthic surveys were collected using a Reef Visual Census (RVC) first established by Smith et al. (2011). RVC protocol has a singular diver collecting reef-fish data within a circular plot with a $15 \mathrm{~m}$ diameter. During the survey the diver collected benthic evaluation data within in the $15 \mathrm{~m}$ diameter and recorded it on waterproof paper (Tables 3-6). A meter stick with $30 \mathrm{~cm}$ markings was used to give reference for habitat sizing of benthic characteristics. Underwater cameras were also used to document the benthic community. Average time taken to conduct the survey was 20 minutes. 


\subsubsection{Macroalgal species}

The most dominant genra of macroalgae found on the Florida Reef Tract were Halimeda spp. and Dictoyta spp. (Yniguez, 2007; Banks et al., 2008). For this study the species that were most commonly found at the dive sites were Halimeda tuna, Halimeda opuntina, and Dictyota menstrualis. Halimeda spp. is in the group Chlorophyta and classified in the jointed calcareous group with heavy calcification (Hurd et al., 2014, Padilla, 1984). Halimeda spp. has a high calcium carbonate composition that can make up to $50-90 \%$ of the species dry weight (Paul and Fenical, 1983). The primary species of Dictotyta spp. sampled in this study was Dictyota menstrualis. Dictoyta spp. is in the group Phaeophyta and their function-form is sheet, which is a noncalcifying filamentous functional group (Hurd et al., 2014, Padilla, 1984).

A total of 4 macroalgae were collected on each individual sampling dive. These samples were then put on ice until they could be processed. An underwater camera was used to take a picture of each sample collected, and used later for identification purposes. While other species were collected the vast majority was either Halimeda spp. or Dictoyta spp. and therefore other genera were not included in the results. Prior to analysis, samples were rinsed with deionized water to remove all salt, sand, and debris (Futch et al., 2011, Lamb et al., 2012). Samples were then dried in an oven at around 40$50^{\circ} \mathrm{C}$ until completely dry. Dried samples were then ground into a fine powder using mortar and pestle. If the sample was a calcifying species then half of the sample was treated with a decarbonizing process in which they were reacted with $10 \% \mathrm{HCl}$ (overnight) for three days, followed by three rinses of deionized water (Nielson, 2010). The other half of the calcifying species' samples remained untreated and were saved for 
nitrogen analysis. Average percent inorganic carbon measured in dry weight of Halimeda spp. sampled in this study was $88.3 \% \pm 4.0$.

\subsubsection{Sponges}

Boring, basket, and clonoid sponges were collected with the most dominant sponge species being Xestospongia muta, Cliona delitrix, Cliona lampa, and Aplysina

cauliformis. At each diving sites 4 sponge species were collected and prepared for stable isotope analysis using the same procedure as the macroalgal species. Average percent inorganic carbon of calcifying sponges dry weight was $52.2 \% \pm 2.7$.

\subsubsection{Surface sediment}

Grab samples of surface sediment were collected at 4 different sites in the dry season in the months of January to March in 2014. Samples were collected from the upper $\mathrm{cm}$ of the floor of the ocean. Much of the Florida Reef Tract sediment is made up of Halimeda spp. (Veyera et al., 2001). All samples were treated with the decarbonizing process and were prepared for stable isotope analysis with the same procedure as biota samples.

\subsubsection{Marquesas Keys core sampling}

An $85 \mathrm{~cm}$ core was collected from Marquesas Keys on February 15, 2013 in the middle of Mooney Harbor. The core was cut into $1 \mathrm{~cm}$ sections that were subsequently subsampled for stable isotope analysis. All samples were treated with a decarbonizing process and prepared for stable isotope analysis with the same procedure as the biotic samples. Average inorganic carbon accounted for $95.5 \% \pm 1.8$ of the total dry weight. 


\subsection{Stable isotope analysis}

Dried and homogenized samples were weighed into tin cups for $\delta^{13} \mathrm{C}$ and $\delta^{15} \mathrm{~N}$ analysis (2-3 mg for macroalgal samples, $0.4-0.7 \mathrm{mg}$ for sponge samples, and $20 \mathrm{mg}$ per sediment sample). All samples were analyzed using standard procedures for elemental analyzer isotope ratio mass spectrometry (EA-IRMS) at the SERC Stable Isotope Lab (SERC/SIL) on Florida International University’s Biscayne Bay Campus.

\subsection{Data analysis}

All differences and comparisons of $\delta^{13} \mathrm{C}$ and $\delta^{15} \mathrm{~N}$ by location were tested using the Mann-Whitney U test with significant differences determined at a 95\% confidence ( $p$ $<0.05)$. Correlations between variables were found using Spearman's rank correlation coefficient. Linear regressions were plotted when variables displayed a significant correlation. Distance data were measured using ArcMap 10.2. Principle Component Analysis was used to establish primary components of benthic community as well as differences between sites. Data Contour maps were made in Surfer 12.0 using the Kriging method, which creates an interpolated grid based on dataset (Swart et al., 2013)

\section{RESULTS}

\subsection{Spatial and temporal variation}

No temporal changes were established for $\delta^{15} \mathrm{~N}$ and $\delta^{13} \mathrm{C}$ in any of the species groups $(\mathrm{P}>0.05)$ (Fig. 5). Since there were no temporal differences, wet and dry season isotope values were combined to obtain mean $\delta^{15} \mathrm{~N}$ or $\delta^{13} \mathrm{C}$ values at each of the individual sites. Mean $\delta^{15} \mathrm{~N}$ values of biota for each region plotted against longitudinal coordinates (decimal degrees) demonstrate an East to West depletion trend (Fig. 6-8). 
The $\delta^{15} \mathrm{~N}$ values for the majority of biotic samples tested were relatively enriched the closer the species was collected to the shoreline (further east).

Enrichment closer to shore was exhibited in Halimeda spp. and sponge species measured $\delta^{15} \mathrm{~N}$ values $(\mathrm{P}=0.01, \mathrm{P}<0.001$, Fig. 9-12, Table 7). Alternatively, Dictoyta spp. measured $\delta^{15} \mathrm{~N}$ values did not display a relationship relative to distance from shore (Table 7). $\delta^{13} \mathrm{C}$ data for sponge and Dictoyta spp. data revealed limited spatial trends. Halimeda spp. values indicated depletion in the heavier isotope with increased distance from the outfalls $(\mathrm{P}<0.001$, Table 7).

\subsection{Reef line comparison}

Reef line $\delta^{13} \mathrm{C}$ and $\delta^{15} \mathrm{~N}$ variation was observed and for all regions each of the biota groups (Tables 8-10). Halimeda spp. sampled at all sites on the first reef line were found to be significantly more enriched than those collected on the third reef line (4.9\%o $\pm 0.6,3.9 \%$ $\pm 0.5, \mathrm{P}=0.01)($ Fig 13$)$. Furthermore, there was a continued depletion of $\delta^{15} \mathrm{~N}$ for Halimeda spp. when comparing the second to the third reef line $(4.6 \% \pm 0.5$, $3.9 \% \pm 0.5, \mathrm{P}=0.01$ ) (Fig.13). There were no significant $\delta^{13} \mathrm{C}$ variations for Halimeda spp. across the three reef lines.

Dictoyta spp. $\delta^{15} \mathrm{~N}$ showed a significant difference between the first and third reef line $(4.4 \%= \pm 0.5,4.0 \% \pm \pm 0.5, \mathrm{P}=0.002)($ Fig. 13$) . \delta^{15} \mathrm{~N}$ values for Dictoyta spp. on the second reef line were more depleted than those sampled on the first, but this difference was not found to be significant $(4.4 \%= \pm 0.5,4.1 \% \pm \pm 0.9, \mathrm{P}=0.1)$ (Fig. 13). Similar to Halimeda spp., Dictoyta spp. displayed an enrichment of $\delta^{13} \mathrm{C}$ values along the first reef line, compared to the second and the third $\left(-14.3 \%_{0} \pm 1.0,-15.2 \%_{0} \pm 0.8,-15.5 \%_{0} \pm 0.9, \mathrm{P}\right.$ $=0.07, \mathrm{P}=0.08)($ Fig. 13) 
Sponge species showed significant $\delta^{15} \mathrm{~N}$ depletion from the first to the second reef line $\left(6.6 \% \%_{0} \pm 1.2,5.9 \% \neq \pm 0.9, \mathrm{P}=0.02\right)$ (Fig. 13). A significant depletion of $\delta^{15} \mathrm{~N}$ values was displayed for sponge species from the inner to the outer ridge complex $(6.6 \% \pm 1.2$, $5.7 \% \pm 0.9, \mathrm{P}=0.01)\left(\right.$ Fig. 13). $\delta^{13} \mathrm{C}$ sponge values suggest significant enrichment from the first to the third reef line $(-17.9 \%$ $\pm 1.2,-18.7 \% 0 \pm 0.9,-18.8 \% 0 \pm 1.1, \mathrm{P}=0.03, \mathrm{P}=$ 0.05) (Fig. 13).

\subsection{Variation with respect to distance from inlet and outfalls}

Combined Hollywood and Miami-Dade distance data exhibited a negative correlation with sponge $\delta^{15} \mathrm{~N}$ values ( $\mathrm{P}=0.01$, Table 7, Fig. 14). $\delta^{15} \mathrm{~N}$ signature of Halimeda spp. was depleted with increased distance from inlet but this correlation was not significant $(\mathrm{P}=0.1$, Table 7$)$. Dictoyta spp. was the only biota to show a negative correlation with $\delta 15 \mathrm{~N}$ and distance from Haulover Inlet $(\mathrm{P}=0.003$, Table 7). Linear regression did not display a significant relationship (Fig. 15).

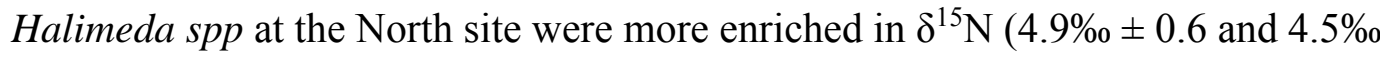
$\pm 0.5, \mathrm{P}=0.04)$ and sponge $(7.0 \% 0 \pm 0.6,5.4 \% 0 \pm 0.4, \mathrm{P}<0.001)$ than South sites. Enrichment in $\delta^{13} \mathrm{C}$ values for Dictoyta spp. found at South sites relative to North sites ($13.5 \% \pm 1.7,-15.6 \% \pm \pm 1.5, \mathrm{P}=0.003)$. Dictoyta spp. exhibited increased enrichment in $\delta^{15} \mathrm{~N}$ values at the South sites compared to the North $(4.6 \% \pm \pm 0.6,4.0 \% \pm \pm 0.5, \mathrm{P}<$ $0.001)$

\subsection{Sediment core and reef sediment comparison}

The Florida Reef Tract and Marquesas Keys have a similar benthic community and therefore sediment stable isotopic analysis should provide suitable comparisons. The first $1 \mathrm{~cm}$ of the Marquesas Keys portion of the core had a $\delta^{15} \mathrm{~N}$ value of $0.5 \%$ and a $\delta^{13} \mathrm{C}$ 
of -12.3\%o (Fig. 17 and Fig. 18). Marquesas keys $\delta^{13} \mathrm{C}$ and $\delta^{15} \mathrm{~N}$ values remained relatively consistent over the $85 \mathrm{~cm}$ as average isotope values for carbon was $-9.0 \% \pm \pm 0.5$ and nitrogen was $0.8 \% \neq \pm 0.4$. The average percent organic carbon and nitrogen measured for the core was $0.3 \% \pm 0.1$ and $36.5 \% \pm 2.0$, respectfully. Sediment samples collected on the Florida Reef Tract at the North and South sites had a mean $\delta^{15} \mathrm{~N}$ value of $7.2 \%_{0} \pm 0.5$ and a percent nitrogen value of $6.0 \% \pm 0.5$. The $\delta^{13} \mathrm{C}$ values measured for sediment collected along the reef tract averaged $-17.3 \% \pm \pm 0.5$. Florida Reef Tract sediment $\delta^{15} \mathrm{~N}$ and $\delta^{13} \mathrm{C}$ and values did not significantly differ between the North and South sites. The Marquesas Keys core was dated using ${ }^{210} \mathrm{~Pb}$ measurements. The upper $23 \mathrm{~cm}$ of the sampled core is dated to before 1837 .

\subsection{Benthic surveys}

Negative correlations were established with depth and $\delta^{15} \mathrm{~N}$ values of Halimeda spp. $(\mathrm{P}=0.02$, Fig. 19) and an insignificant correlation was found for Dictoyta spp. and sponge $(\mathrm{P}=0.4, \mathrm{P}=0.2)$. A positive relationship was shown between live coral and $\delta^{13} \mathrm{C}$ values of Halimida spp. $(\mathrm{P}=0.05)$. Mean live coral percent for all sites across the first to third reef line $(13 \% \pm 2.6,7.0 \% \pm 2.7,12.8 \% \pm 2.7)$. The Haulover sites had the highest mean percent live coral on all three-reef lines, but this difference was not significant $(\mathrm{P}=$ 0.2). Percent soft sponge cover increase had a negative correlation with $\delta^{13} \mathrm{C}$ of sponge.

When evaluating relationships benthic relationships with each other, the data displayed a negative correlation with live coral percent and both depth and distance from shore. Percent hard algae $(>1 \mathrm{~mm})$ and hard sponge decreased the closer these species were to Haulover inlet $(\mathrm{P}<0.05)$. Both size classes of hard algal cover have a significant negative correlation with hard sponges $(\mathrm{P}=0.05, \mathrm{P}<0.001)$. The strongest relationships 
established in the PCA was between hard algal cover $>1 \%$, hard octocoral cover $\%$, and hard sponge \% (Table 11). PCA revealed no clustering between sites (Fig. 22).

\section{DISCUSSION}

\subsection{Spatial variation}

$\delta^{15} \mathrm{~N}$ data values displayed relatively enriched values closer to shore for all three sampled biota groups. Relative enrichment of $\delta^{15} \mathrm{~N}$ was significantly more evident in both Halimeda spp. and sponges. Enrichment of $\delta^{15} \mathrm{~N}$ from East to West was shown more clearly for Halimeda spp. and sponges in Fig. 11 and Fig. 12 when values within $1000 \mathrm{~m}$ were extrapolated. While there is a natural gradient of enrichment of biota closer to shore when there are no anthropogenic influences present, the relative enrichment of all data in the present study to previous studies displays these sites are particularly perturbed (Table 12).

Previous studies evaluating the $\delta^{13} \mathrm{C}$ and $\delta^{15} \mathrm{~N}$ signature of the same species did not find spatial variation with respect to distance from terrestrial sources of nutrients (Anderson et al., 2010; Cocheret de la Moriniere et al., 2003; Hitling et al., 2013; Lamb et al., 2012). $\delta^{15} \mathrm{~N}$ values for all biota and sediment samples from this study were enriched compared to studies in and outside of the South Florida region (Table 12). One possible explanation for the enrichment in $\delta^{15} \mathrm{~N}$ along the Florida Reef Tract biota is the proximity of the Florida Reef Tract sites to a highly urbanized shoreline. While the Lamb et al. (2012) study also sampled along the Florida Reef Tract, the Upper Keys have much less coastal urbanization compared to Miami-Dade and Broward counties. The researchers in the Upper Keys report concluded that variations in nitrogen isotopes were associated with the nitrification process and not anthropogenic sources. Also, the 
community structure and species diversity of the Florida Reef Tract is different than that observed in the Keys, Bahamas, and Caribbean (Banks et al., 2008). The comparison of data from this study to those in different regions supports the hypothesis that anthropogenic sources of nutrients are been uptaken by biota.

Nutrient enrichment of marine biota by natural sources is likely not the source of isotopic enrichment observed in this study. Resuspension of sediment is improbable as there were no significant tropical storms or weather conditions that would accelerate this process. Upwelled nitrate has been measured along the Florida Reef Tract at about 4.8\%o (Leichter et al, 2007). Upwelled water driven by the Florida current is frequently measured below $20^{\circ} \mathrm{C}$ (Smith, 1983). The coldest measured temperature found at this study's sites was $23^{\circ} \mathrm{C}$. Measured temperature in this study was relatively consistent and over the entire sampling period fluctuated a total of $6.4^{\circ} \mathrm{C}$. Upwelling occurrences in Florida document drastic fluctuation in temperature (Smith, 1983).

\subsection{Reef line variation}

Reef line comparisons in this study show the largest variation in $\delta^{13} \mathrm{C}$ and $\delta^{15} \mathrm{~N}$. The $\delta^{15} \mathrm{~N}$ values for the biota collected exhibit a clear relationship relative to reef line location. The largest differences between reef lines were found between the inner and the outer reef complex. All biota indicated depletion in the heavier nitrogen isotope from the inner to the outer reef line. Intuitively, reef line isotope data should show similar trends to spatial variation due to the natural parallel nature of the inner, middle, and outer ridge complexes to the shoreline. This trend was displayed in Halimeda spp. and sponge $\delta^{15} \mathrm{~N}$ values. Dictoyta spp., however, showed the opposite trend with correlation to distance from shore (which suggested that Dictoyta spp. were more enriched closer to shore). 
When isolating the Dictoyta spp. by reef line the $\delta^{15} \mathrm{~N}$ values presents a depletion trend from the inner, middle, and outer reef complexes. Therefore, this data may suggest that differences between $\delta^{15} \mathrm{~N}$ could be dependent upon inner, middle, and outer substrate composition variances not measured in the benthic survey. The benthic characteristics measured in this study does not support this theory, however, as there was no significant differences in benthic composition or morphology between reef lines.

\subsection{Influence of Haulover inlet and outfalls}

Dictoyta spp. did not show a relationship between $\delta^{15} \mathrm{~N}$ values with relation to increased distance from shore. Concurrently, Dictoyta spp. $\delta^{15} \mathrm{~N}$ values were significantly enriched if these species were adjacent to either Haulover inlet. Although a statistical interaction was unable to be attributed to the phenomenon, the data implies that the Haulover inlet altered the natural nutrient enrichment patterns of Dictoyta spp. on the Florida Reef Tract. Isotopic data implies that Dictoyta spp. were the most heavily influenced biota by inlets. While sponge $\delta^{15} \mathrm{~N}$ values did not reflect a relationship with distance to inlet, these values did show an enrichment of the heavier isotope the closer these species were to both outfalls. Sponge species have been shown to have all pathways of nitrogen biogeochemistry occurring (Flore et al., 2013). Sponges uptake particular organic nitrogen and DIN from the water column and provide large amounts of DIN to coral reefs, through processes such as denitrification, nitrificiation, and annamox (Flore et al., 2013). Therefore, sponges are more susceptible to nitrogen loading by ocean outfalls, as they will directly assimilate these nutrients.

Halimeda spp. $\delta^{15} \mathrm{~N}$ values displayed no relationship with distance from anthropogenic sources. However, this may be due to an interaction between geographical 
positioning and location of anthropogenic source. Both outfalls discharge on the third reef line. Therefore, Halimeda spp. may be already increasingly depleted in nitrogen due to the measured land to sea gradient of depletion. In this case $\delta^{15} \mathrm{~N}$ may not reflect the intensity enrichment obtained from ocean outfalls. Ideally measuring isotopes of biota adjacent to outfalls that discharge on the first reef line would provide a better analysis of natural gradient and anthropogenic source influence.

In theory, Haulover site data should be the most perturbed site as these sites are located adjacent to two major point sources. The $\delta^{13} \mathrm{C}$ and $\delta^{15} \mathrm{~N}$ data presented in this study did not support that assumption. In fact, the North site's $\delta^{13} \mathrm{C}$ and $\delta^{15} \mathrm{~N}$ values indicate a higher anthropogenic influence with increased enrichment closer to shore and to the Hollywood outfall. To isolate the differences of a highly anthropogenic influenced Florida Reef Tract region versus a less perturbed reef site, the North and the South site regions were compared isotopically. The South sites, which on average were further from shore and were not next to a point anthropogenic source of pollution, served as the less perturbed site isotopically compared to the North. Overall the South sites isotopic values reflected less human inputs of nutrients supporting the claim that biota that biota at the South sites are less impacted. The majority of biota samples measured showed an enrichment of $\delta^{13} \mathrm{C}$ and a depletion of $\delta^{15} \mathrm{~N}$ compared to the North sites. The only biota that did not follow this trend was the Dictoyta spp., which was more depleted in $\delta^{15} \mathrm{~N}$ in the North site. This finding correlates with the previous conclusion that Dictoyta spp. $\delta^{15} \mathrm{~N}$ values increase with distance from shore. 


\subsection{Sediment core and reef sediment comparison}

The geographical location of Marquesas Keys allows for limited human nutrient inputs. There are no point sources of anthropogenic pollution and diminutive human interaction around the islands. The core was taken in a semi-enclosed, Mooney Harbor, and is therefore very susceptible to natural terrestrial runoff from the dominant mangrove species. While terrestrial runoff can produce high loads of nitrate into a marine source these nutrients do not display enriched $\delta^{15} \mathrm{~N}$ values (Swart et al., 2013). These qualities make the Marquesas Keys a significant proxy for understanding how an unaltered marine system looks isotopically. Marquesas Keys $\delta^{15} \mathrm{~N}$ values display a small range over 100 years in which there is little variation in the isotopic ratio. Therefore, in an unaltered marine system $\delta^{15} \mathrm{~N}$ values should remain consistent when sources of nitrogen are not shifted.

The exceedingly elevated $\delta^{15} \mathrm{~N}$ values that were measured for sediment sampled along the Florida Reef Tract relative to the core, demonstrate that the Florida Reef Tract is obtaining human influenced nutrients. It is important to note that differences in isotope values may be influenced by the variations in the benthic community. Thalassia sp. is present at Marquesas Keys, while no sea grass species were observed along the Florida Reef Tract. A sea grass study in the Upper and Lower Keys presented an isotopic range for Thalassia of -7.2 to $-10.4 \%$ for $\delta^{13} \mathrm{C}$ and 1.1 to $2.1 \%$ for $\delta^{15} \mathrm{~N}$. Therefore, the presence of Thalassia at Marquesas Keys likely is the reason for the $\delta^{13} \mathrm{C}$ variation seen at the two sites. Seagrass species $\delta^{13} \mathrm{C}$ values are distinct from other marine plants, while $\delta^{15} \mathrm{~N}$ values tend to fall with in the same range as macroalgaes. 
Over the past twenty years the sediment core shows a shift to increasingly more depleted carbon values. An increased depletion of carbon isotopes overtime can suggest an increased anthropogenic influence (Swart et al., 2013). However, this is most likely not the case for the Marquesas keys core. The shift in $\delta^{13} \mathrm{C}$ values can be explained by increased mangrove influence, as mangrove $\delta^{13} \mathrm{C}$ values tend to fall within the common range measured in $C_{3}$ plants (Kuramoto and Minagawa, 2000). $C_{3}$ plants are increasingly more depleted in $\delta^{13} \mathrm{C}$ than marine macroalgaes and seagrass species (Table 1).

Therefore, isotopic values of Marquesas Keys sediment could be influenced by increased mangrove carbon inputs

\subsection{Benthic survey}

Benthic community survey analyses suggest that abiotic factors do not significantly alter isotopic data. Depth was the primary benthic factor that exhibited relationships with $\delta^{13} \mathrm{C}$ and $\delta^{15} \mathrm{~N}$ values for biota. Lapointe et al. (2005) supports the idea that depletion of $\delta^{15} \mathrm{~N}$ values as depth increases is an indication of land-based sources of nutrients. This study's $\delta^{15} \mathrm{~N}$ values measured for Halimeda spp. displayed this phenomenon as values were relatively enriched at shallower sites. In addition to depth, variation in substrate composition and morphology among reef tracts can impact benthic composition (Banks et al., 2008). Our study however did not show a difference between benthic community structures across the reef lines. The PCA analysis suggests that there are no spatial gradients driving the data. Lack of variation when measuring benthic community dynamics may be due to limited sampling or factors not being measured. Interestingly, Haulover sites showed the most live coral cover. Also, the second reef line sites had the lowest mean percent live coral mean. Live coral cover percent data 
measured in this study indicate that live coral survive and thrive in presence of large anthropogenic point sources of nutrients. This data also indicates that other factors are contributing to benthic characteristics.

The negative correlation between percent hard algae and sponge cover indicate that there is competition for space among the benthic biota. While the data does not indicate an influence on live coral cover, this relationship could have consequences on coral reef structure. Hard macroalgae are essential in maintaining a calcareous structure for live coral recruitment. Consequently, if sponges are able to outcompete hard macroalgae over a significant period of time coral reef dynamics could be severely altered (Ward-Paige et al., 2005). Data from this study suggest that nutrients from Haulover Inlet have negative impacts on percent cover of hard algae and hard sponge groups. This impact can be attributed to the high levels of virus prevalence found by Futch et al. (2009) in inlets. High levels of virus prevalence are due to septic tank use and nonpoint pollution into Biscayne Bay.

\section{CONCLUSIONS}

The data presented in this study shows enrichment in $\delta^{15} \mathrm{~N}$ close to the shoreline of southeast Florida. The level of enrichment measured in this study indicates that major inputs of nutrients near shore are derived from anthropogenic sources. While it is advised not to attribute any $\delta^{15} \mathrm{~N}$ findings for marine species less than $8 \%$ to anthropogenic sources, the strength of the relationships and comparisons found in this study suggest human inputs are altering benthic coral reef system dynamics. Also, $\delta^{15} \mathrm{~N}$ values of sponge indicate that ocean outfalls and inlets can alter the natural nutrient uptake in sponges. 
This study reveals while historically the ocean has been cited as an effective dilutor of human nutrients, complications in oceanography make quantifying dilution challenging. While the $\delta^{15} \mathrm{~N}$ values of biota suggest that outfalls are impacting benthic macroalgae and sponges, these species isotopic values propose that near shore anthropogenic sources play a stronger role. Furthermore, it is important to note that isotopic differences across the inner, middle, and outer reef complexes between all biota were revealed. This finding is presumably attributed to shoreline enrichment as the inner reef line displayed the most enriched $\delta^{15} \mathrm{~N}$ values. Further investigation would need to be done in order to explore additional reef line benthic and morphologic characteristics that could create this variation.

Prior studies evaluating the isotopic signatures of Halimeda spp., Dictoyta spp., and a variety of sponge species measure relatively depleted values of $\delta^{15} \mathrm{~N}$ relative to those measured in this project. While there tends to be spatial and temporal changes in $\delta^{15} \mathrm{~N}$ individual species depending on the region sampled and when it was sampled, the studies evaluated were conducted across different regions over a 10 year period and their average $\delta^{15} \mathrm{~N}$ values were with in $1 \%$ (Table 12). As the average values found in the present study for Halimeda spp., Dictoyta spp., and sponge in this study were almost 3\%o greater for $\delta^{15} \mathrm{~N}$ than the aforementioned studies. A previous stable isotope study evaluating algae and cyanobacteria (Anderson et al. 2010) suggested that the use of transects would provide a more effective sampling design when evaluating stable isotopic variation adjacent to major sources of anthropogenic nutrients. The current studies data indicates that transects do not necessarily show clear patterns of point sources of pollution (especially with $\delta^{13} \mathrm{C}$ analysis), likely due to ocean dynamics. 
As previously stated natural processes can alter isotopic values of both $\delta^{13} \mathrm{C}$ and $\delta^{15} \mathrm{~N}$ in marine organisms. Fractionation during processes such as assimilation, nitrification, and denitrification could potentially influence $\delta^{15} \mathrm{~N}$ values of biota (Anderson, 2010). Uncertainty remains about the fractionation during assimilation of nitrate and ammonium in marine species. Recent studies have estimated a fractionation factor of 1.002 and 1.010 (Swart et al., 2013). Even though these values are uncertain it is important to keep in mind that natural processes could be credited for relative enrichment or depletion of isotopic values.

A major limitation of this study was the restricted sampling period. Ideally this study should be conducted over multiple years in order to get a more robust data set. Increased sampling time would aid in a better understanding of how isotopic values change in this region over time. Also, this project was limited by weather (particularly in the wet season) and diving conditions. These setbacks made completing certain transects across all three-reef lines impossible. In order to improve benthic survey reliability, diver uniformity is suggested as personal biases in measurement may alter the benthic composition interpretation. Stable isotope data investigation would have benefited from measuring $\delta^{15} \mathrm{~N}$ and $\delta^{18} \mathrm{O}$ of $\mathrm{NO}_{3}$-in the water column, as it has been shown to be a good indicator of anthropogenic sources (Swart et al., 2013). Additionally, analyzing $\delta^{34} \mathrm{~S}$ could strengthen marine isotope studies, as marine and terrestrial sources of sulfur isotope values vary more than $\delta^{13} \mathrm{C}$ and $\delta^{15} \mathrm{~N}$ (Tucker et al., 1999; Sweeny et al., 1981).

Continued monitoring of the Florida Reef Tract is needed to determine dynamics of the benthic community and the decline of the coral population (Lirman and Biber, 2005). While the conservation efforts for the Florida Reef Tract have been positive the 
regional coral cover is still under $10 \%$ and continually declining. More stringent government action and a change in attitude in the local and regional community are needed for the reef tract to survive (Jackson et al., 2014). 


\section{TABLES}

Table 1. $\delta^{13} \mathrm{C}$ distribution in the environment

\begin{tabular}{lc}
\hline Source & $\boldsymbol{\delta}^{\mathbf{1 3}} \mathbf{C}(\mathbf{\% o})$ \\
\hline $\mathrm{CO}_{2}(\mathrm{~atm})$ & -8 \\
$\mathrm{CO}_{2}(\mathrm{aq})$ & -8 \\
$\mathrm{HCO}_{3}^{-}(\mathrm{aq})$ & $\sim 0$ \\
Seagrass & -9 to -14 \\
Plankton & -18 to -25 \\
$\mathrm{C}_{3}$ plants & -28 \\
\hline
\end{tabular}

Isotopic table created from multiple references (Anderson and Fourqueran, 2004; Anderson et al., 2010; Brian and Fry, 1987; Risk et al., 2009).

Table 2. $\delta^{15} \mathrm{~N}$ distribution in the environment

\begin{tabular}{lc}
\hline Source & $\boldsymbol{\delta}^{\mathbf{1 5}} \mathbf{N}(\mathbf{\% o})$ \\
\hline $\mathrm{N}_{2}(\mathrm{~atm})$ & 0 \\
Deep water $\mathrm{NO}_{3}{ }^{-}$ & +4 to +6 \\
$\mathrm{NH}_{4}{ }^{+}(\mathrm{aq})$ & -2 to 0 \\
Fertilizer $\mathrm{N}$ & -3 to +3 \\
Marine & +4 to +6 \\
$\mathrm{C}_{3}$ plants & $<+5$ \\
Effluent & $>+8$ \\
\hline
\end{tabular}

Isotopic table created from multiple references (Anderson and Fourqueran, 2004; Anderson et al., 2010; Brian and Fry, 1987; Risk et al., 2009). 
Table 3. RVC Benthic survey data for sites recorded (A)

\begin{tabular}{|c|c|c|c|c|c|c|}
\hline SITE & Hard relief $(\mathrm{m})$ & Soft relief $(\mathrm{m})$ & Sand $\%$ & Bare \% & S Macroalgae \% & S Gorgonian (\%) \\
\hline N1BA & 0.75 & 1.25 & 30 & 95 & 5 & 0 \\
\hline $\mathrm{N} 1 \mathrm{CA}$ & 0.50 & 1.00 & 30 & 95 & 0 & 0 \\
\hline $\mathrm{N} 1 \mathrm{CB}$ & 0.50 & 1.00 & 30 & 80 & 10 & 0 \\
\hline $\mathrm{N} 1 \mathrm{CC}$ & 0.50 & 1.25 & 15 & 0 & 90 & 0 \\
\hline $\mathrm{N} 2 \mathrm{AA}$ & 1.22 & 0.31 & 30 & 45 & 35 & 0 \\
\hline $\mathrm{N} 2 \mathrm{AB}$ & 0.31 & 0.61 & 40 & 80 & 10 & 0 \\
\hline $\mathrm{N} 2 \mathrm{AC}$ & 0.46 & 0.61 & 30 & 10 & 80 & 0 \\
\hline $\mathrm{N} 2 \mathrm{CA}$ & 3.00 & 1.00 & 20 & NM & NM & NM \\
\hline $\mathrm{N} 2 \mathrm{CB}$ & 1.00 & 0.50 & 45 & 20 & 80 & 0 \\
\hline $\mathrm{N} 2 \mathrm{CC}$ & 0.30 & 1.00 & 10 & 5 & 10 & 55 \\
\hline N4BA & 3.00 & 0.75 & 5 & 50 & 25 & 0 \\
\hline N4BB & 0.00 & 1.00 & 95 & 5 & 95 & 0 \\
\hline N4BC & 0.60 & 1.00 & 10 & 25 & 35 & 0 \\
\hline H1AA & 1.00 & 2.00 & NM & 85 & 10 & 0 \\
\hline $\mathrm{H} 1 \mathrm{AB}$ & NM & NM & NM & 10 & 80 & 0 \\
\hline $\mathrm{H} 1 \mathrm{AC}$ & 0.50 & 1.00 & 20 & 80 & 20 & 0 \\
\hline $\mathrm{H} 2 \mathrm{CA}$ & 1.00 & 1.00 & 5 & 85 & 5 & 0 \\
\hline $\mathrm{H} 2 \mathrm{CB}$ & 1.00 & 2.50 & 20 & 60 & 30 & 0 \\
\hline $\mathrm{H} 2 \mathrm{CC}$ & 2.50 & 2.50 & 10 & 80 & 10 & 0 \\
\hline H4AA & 0.53 & 0.76 & 40 & 95 & 5 & 0 \\
\hline $\mathrm{H} 4 \mathrm{AB}$ & 0.61 & 0.91 & NM & 60 & 5 & 0 \\
\hline $\mathrm{H} 4 \mathrm{AC}$ & 1.22 & 0.91 & 5 & 55 & 25 & 0 \\
\hline $\mathrm{H} 5 \mathrm{CC}$ & 0.91 & 1.50 & 40 & 85 & 10 & 0 \\
\hline S1AA & 0.60 & 1.00 & 15 & 2 & 28 & 0 \\
\hline S1AB & 1.00 & 1.50 & 25 & 5 & 5 & 0 \\
\hline S1AC & 2.00 & 1.50 & 20 & 5 & 20 & 0 \\
\hline $\mathrm{S} 3 \mathrm{CA}$ & 1.30 & 2.00 & 20 & 5 & 45 & 0 \\
\hline $\mathrm{S} 3 \mathrm{CB}$ & 0.75 & 0.50 & 70 & 90 & 0 & 0 \\
\hline $\mathrm{S} 3 \mathrm{CC}$ & 1.00 & 0.50 & 25 & 95 & 5 & 0 \\
\hline $\mathrm{S} 4 \mathrm{CA}$ & 0.91 & 0.61 & 10 & 80 & 20 & 0 \\
\hline $\mathrm{S} 4 \mathrm{CB}$ & 0.50 & 0.75 & NM & 10 & 80 & 0 \\
\hline $\mathrm{S} 4 \mathrm{CC}$ & 0.50 & 0.75 & 30 & NM & NM & NM \\
\hline S5CA & 0.50 & 0.75 & 10 & 100 & 0 & 0 \\
\hline $\mathrm{S} 5 \mathrm{CB}$ & 0.50 & 1.00 & NM & 80 & 20 & 0 \\
\hline S6CC & 0.30 & 0.60 & 35 & 15 & 20 & 0 \\
\hline
\end{tabular}

* Titles that have an $\mathrm{H}$ in front of them are hard species, while titles with an $\mathrm{S}$ in front are soft species 
Table 4. RVC Benthic survey data for sites recorded (B)

\begin{tabular}{|c|c|c|c|c|c|}
\hline SITE & S Sponge \% & S Zooanthid \% & S Octocoral \% & Rubble \% & Hardbottom \% \\
\hline N1BA & 0 & 0 & 0 & 20 & 50 \\
\hline N1CA & 5 & 0 & 0 & 40 & 30 \\
\hline $\mathrm{N} 1 \mathrm{CB}$ & 10 & 0 & 0 & 10 & 60 \\
\hline $\mathrm{N} 1 \mathrm{CC}$ & 10 & 0 & 0 & 5 & 80 \\
\hline N2AA & 20 & 0 & 0 & 0 & 70 \\
\hline $\mathrm{N} 2 \mathrm{AB}$ & 10 & 0 & 0 & 10 & 50 \\
\hline $\mathrm{N} 2 \mathrm{AC}$ & 10 & 0 & 0 & 10 & 60 \\
\hline $\mathrm{N} 2 \mathrm{CA}$ & NM & NM & NM & 10 & 70 \\
\hline $\mathrm{N} 2 \mathrm{CB}$ & 0 & 0 & 0 & 0 & 65 \\
\hline $\mathrm{N} 2 \mathrm{CC}$ & 30 & 0 & 0 & 35 & 55 \\
\hline N4BA & 25 & 0 & 0 & 25 & 70 \\
\hline N4BB & 0 & 0 & 0 & 0 & 5 \\
\hline N4BC & 20 & 20 & 0 & 60 & 30 \\
\hline H1AA & 5 & 0 & 0 & NM & NM \\
\hline $\mathrm{H} 1 \mathrm{AB}$ & 10 & 0 & 0 & NM & NM \\
\hline $\mathrm{H} 1 \mathrm{AC}$ & 0 & 0 & 0 & 10 & 70 \\
\hline $\mathrm{H} 2 \mathrm{CA}$ & 10 & 0 & 0 & 10 & 85 \\
\hline $\mathrm{H} 2 \mathrm{CB}$ & 10 & 0 & 0 & 0 & 80 \\
\hline $\mathrm{H} 2 \mathrm{CC}$ & 10 & 0 & 0 & 10 & 80 \\
\hline H4AA & 0 & 0 & 0 & 10 & 50 \\
\hline $\mathrm{H} 4 \mathrm{AB}$ & 15 & 0 & 20 & NM & NM \\
\hline $\mathrm{H} 4 \mathrm{AC}$ & 20 & 0 & 0 & 10 & 85 \\
\hline $\mathrm{H} 5 \mathrm{CC}$ & 5 & 0 & 0 & 15 & 45 \\
\hline S1AA & 50 & 20 & 0 & 25 & 60 \\
\hline $\mathrm{S} 1 \mathrm{AB}$ & 75 & 15 & 0 & 45 & 30 \\
\hline S1AC & 45 & 20 & 0 & 10 & 70 \\
\hline $\mathrm{S} 3 \mathrm{CA}$ & 40 & 5 & 0 & 25 & 55 \\
\hline $\mathrm{S} 3 \mathrm{CB}$ & 5 & 0 & 0 & 5 & 25 \\
\hline $\mathrm{S} 3 \mathrm{CC}$ & 0 & 0 & 0 & 10 & 65 \\
\hline S4CA & 0 & 0 & 0 & 5 & 85 \\
\hline S4CB & 10 & 0 & 0 & NM & NM \\
\hline $\mathrm{S} 4 \mathrm{CC}$ & NM & $\mathrm{NM}$ & NM & 20 & 30 \\
\hline S5CA & 0 & 0 & 0 & 10 & 80 \\
\hline S5CB & 0 & 0 & 0 & NM & NM \\
\hline S6CC & 0 & 20 & 0 & 15 & 50 \\
\hline
\end{tabular}

* Titles that have an $\mathrm{H}$ in front of them are hard species, while titles with an $\mathrm{S}$ in front are soft species 
Table 5. RVC Benthic survey data for sites recorded (C)

\begin{tabular}{|c|c|c|c|c|c|}
\hline SITE & Live coral \% & H Algae $<1 \%$ & H Algae $>1 \%$ & H Octocoral \% & H Zooanthid \% \\
\hline N1BA & 5 & 25 & 35 & 10 & 20 \\
\hline N1CA & 10 & 20 & 0 & 40 & 0 \\
\hline $\mathrm{N} 1 \mathrm{CB}$ & 10 & 60 & 10 & 10 & 0 \\
\hline $\mathrm{N} 1 \mathrm{CC}$ & 10 & 40 & 20 & 10 & 0 \\
\hline N2AA & 30 & 30 & 10 & 20 & 0 \\
\hline $\mathrm{N} 2 \mathrm{AB}$ & 5 & 20 & 20 & 40 & 0 \\
\hline $\mathrm{N} 2 \mathrm{AC}$ & 10 & 60 & 0 & 15 & 0 \\
\hline $\mathrm{N} 2 \mathrm{CA}$ & NM & NM & NM & NM & NM \\
\hline $\mathrm{N} 2 \mathrm{CB}$ & 5 & 75 & 0 & 10 & 0 \\
\hline $\mathrm{N} 2 \mathrm{CC}$ & 15 & 20 & 15 & 20 & 10 \\
\hline N4BA & 5 & 10 & 15 & 40 & 0 \\
\hline N4BB & 0 & 100 & 0 & 0 & 0 \\
\hline N4BC & 10 & 10 & 25 & 50 & 0 \\
\hline H1AA & 25 & 5 & 5 & 40 & 0 \\
\hline $\mathrm{H} 1 \mathrm{AB}$ & 10 & 50 & 10 & 20 & 0 \\
\hline $\mathrm{H} 1 \mathrm{AC}$ & 10 & 50 & 10 & 20 & 0 \\
\hline $\mathrm{H} 2 \mathrm{CA}$ & 20 & 5 & 5 & 45 & 0 \\
\hline $\mathrm{H} 2 \mathrm{CB}$ & 10 & 40 & 10 & 20 & 0 \\
\hline $\mathrm{H} 2 \mathrm{CC}$ & 10 & 50 & 10 & 20 & 0 \\
\hline H4AA & 5 & 40 & 30 & 20 & 0 \\
\hline $\mathrm{H} 4 \mathrm{AB}$ & 5 & 10 & 5 & 40 & 0 \\
\hline $\mathrm{H} 4 \mathrm{AC}$ & 15 & 10 & 25 & 20 & 0 \\
\hline $\mathrm{H} 5 \mathrm{CC}$ & 45 & 10 & 15 & 10 & 0 \\
\hline S1AA & 15 & 10 & 10 & 25 & 10 \\
\hline $\mathrm{S} 1 \mathrm{AB}$ & 15 & 10 & 5 & 40 & 5 \\
\hline $\mathrm{S} 1 \mathrm{AC}$ & 10 & 10 & 5 & 35 & 0 \\
\hline $\mathrm{S} 3 \mathrm{CA}$ & 5 & 25 & 15 & 30 & 0 \\
\hline $\mathrm{S} 3 \mathrm{CB}$ & 1 & 5 & 1 & 40 & 0 \\
\hline $\mathrm{S} 3 \mathrm{CC}$ & 1 & 5 & 0 & 30 & 0 \\
\hline $\mathrm{S} 4 \mathrm{CA}$ & 20 & 30 & 30 & 10 & 0 \\
\hline S4CB & 10 & 50 & 20 & 10 & 0 \\
\hline $\mathrm{S} 4 \mathrm{CC}$ & $\mathrm{NM}$ & NM & NM & $\mathrm{NM}$ & NM \\
\hline S5CA & 10 & 70 & 10 & 0 & 0 \\
\hline S5CB & 5 & 60 & 20 & 5 & 0 \\
\hline S6CC & 10 & 5 & 5 & 35 & 0 \\
\hline
\end{tabular}

* Titles that have an $\mathrm{H}$ in front of them are hard species, while titles with an $\mathrm{S}$ in front are soft species 
Table 6. RVC Benthic survey data for sites recorded (D)

\begin{tabular}{|c|c|c|c|c|c|c|}
\hline SITE & H Sponge $\%$ & Depth (m) & Visibility (m) & $\begin{array}{c}\text { Temperature } \\
\left({ }^{\circ} \mathrm{C}\right)\end{array}$ & $\begin{array}{c}\text { Current } \\
\text { speed }\end{array}$ & $\begin{array}{l}\text { Current } \\
\text { direction }\end{array}$ \\
\hline N1BA & 5.0 & 8.2 & 9.1 & 25.5 & Low & NM \\
\hline N1CA & 30.0 & 12.8 & 6.1 & 25.6 & Low & NM \\
\hline $\mathrm{N} 1 \mathrm{CB}$ & 10.0 & 13.4 & 6.1 & 27.8 & Low & North \\
\hline $\mathrm{N} 1 \mathrm{CC}$ & 20.0 & 14.9 & 9.1 & 27.8 & Low & South \\
\hline N2AA & 10.0 & 7.0 & 9.1 & 25.6 & Low & NM \\
\hline $\mathrm{N} 2 \mathrm{AB}$ & 15.0 & 13.7 & 9.1 & 25.6 & Low & NM \\
\hline $\mathrm{N} 2 \mathrm{AC}$ & 15.0 & 15.6 & 9.1 & 27.8 & Low & East \\
\hline $\mathrm{N} 2 \mathrm{CA}$ & NM & 10.7 & 10.7 & 26.7 & Low & South \\
\hline $\mathrm{N} 2 \mathrm{CB}$ & 10.0 & 13.7 & 15.2 & 27.2 & Medium & South \\
\hline $\mathrm{N} 2 \mathrm{CC}$ & 20.0 & 16.8 & 10.7 & 29.4 & High & NM \\
\hline N4BA & 30.0 & 10.7 & 9.1 & 27.8 & NM & NM \\
\hline N4BB & 0.0 & 13.7 & 15.2 & 27.2 & Low & South \\
\hline N4BC & 5.0 & 18.3 & 10.7 & 28.9 & Medium & North \\
\hline H1AA & 25.0 & 7.6 & 6.1 & 27.2 & Low & NM \\
\hline $\mathrm{H} 1 \mathrm{AB}$ & 10.0 & 19.5 & 9.1 & 25.6 & Low & NM \\
\hline $\mathrm{H} 1 \mathrm{AC}$ & 10.0 & 17.4 & 9.1 & 27.8 & $\mathrm{NM}$ & NM \\
\hline $\mathrm{H} 2 \mathrm{CA}$ & 25.0 & 10.7 & 12.2 & 27.2 & None & NM \\
\hline $\mathrm{H} 2 \mathrm{CB}$ & 20.0 & 18.3 & 9.1 & 25.6 & Low & South \\
\hline $\mathrm{H} 2 \mathrm{CC}$ & 10.0 & 16.8 & 9.1 & 27.8 & Low & NM \\
\hline H4AA & 5.0 & 10.8 & 13.7 & 27.2 & low & East \\
\hline $\mathrm{H} 4 \mathrm{AB}$ & 40.0 & 17.5 & 9.1 & 26.7 & Low & NM \\
\hline $\mathrm{H} 4 \mathrm{AC}$ & 20.0 & 16.4 & 9.1 & 26.7 & Low & North \\
\hline $\mathrm{H} 5 \mathrm{CC}$ & 10.0 & 15.9 & 18.3 & 27.2 & High & North \\
\hline S1AA & 30.0 & 10.7 & 4.6 & 23.9 & Low & North/South \\
\hline $\mathrm{S} 1 \mathrm{AB}$ & 25.0 & 17.4 & 3.1 & 25.0 & Low & North/South \\
\hline S1AC & 40.0 & 17.1 & 2.4 & 23.3 & Medium & North/South \\
\hline $\mathrm{S} 3 \mathrm{CA}$ & 20.0 & 9.1 & 3.0 & 25.6 & Medium & NW \\
\hline $\mathrm{S} 3 \mathrm{CB}$ & 40.0 & 14.9 & 3.0 & 23.0 & Low & NW \\
\hline $\mathrm{S} 3 \mathrm{CC}$ & 30.0 & 16.5 & 3.0 & 23.0 & Low & NW \\
\hline $\mathrm{S} 4 \mathrm{CA}$ & 10.0 & 10.1 & 6.1 & 25.0 & Low & N/A \\
\hline S4CB & 10.0 & 13.7 & 13.7 & 26.7 & NM & $\mathrm{NM}$ \\
\hline $\mathrm{S} 4 \mathrm{CC}$ & NM & 15.9 & 6.1 & 26.1 & High & Northeast \\
\hline S5CA & 10.0 & 11.3 & 9.1 & 26.7 & Low & North \\
\hline S5CB & 10.0 & 14.6 & 9.1 & 26.1 & NM & NM \\
\hline S6CC & 45.0 & 15.2 & 15.0 & 23.3 & Low & North/South \\
\hline
\end{tabular}

* Titles that have an $\mathrm{H}$ in front of them are hard species, while titles with an $\mathrm{S}$ in front are soft species 
Table 7. Spearman Rank correlation coefficients between $\delta^{15} \mathrm{~N}$ and $\delta^{13} \mathrm{C}$ of Halimeda spp., Dictoyta spp., and sponge and distance from shore, distance from outfall, distance from inlet and depth.

\begin{tabular}{lcccccc}
\hline & \multicolumn{2}{c}{ Halimeda spp. } & \multicolumn{2}{c}{ Dictoyta spp. } & \multicolumn{2}{c}{ Sponge } \\
\cline { 2 - 7 } & $\delta^{15} \mathrm{~N}$ & $\delta^{13} \mathrm{C}$ & $\delta^{15} \mathrm{~N}$ & $\delta^{13} \mathrm{C}$ & $\delta^{15} \mathrm{~N}$ & $\delta^{13} \mathrm{C}$ \\
\hline Distance from shore & $\mathbf{- 0 . 5 0}$ & 0.10 & -0.05 & -0.13 & $\mathbf{- 0 . 4 9}$ & -0.24 \\
Distance from outfall & -0.10 & $\mathbf{- 0 . 5 9}$ & $\mathbf{0 . 3 4}$ & 0.24 & $\mathbf{- 0 . 4 1}$ & 0.24 \\
Distance from inlet & 0.21 & -0.16 & $\mathbf{- 0 . 3 4}$ & -0.10 & 0.10 & -0.03 \\
Depth & $\mathbf{- 0 . 5 5}$ & 0.0 & -0.18 & 0.12 & -0.01 & -0.09 \\
\hline
\end{tabular}

*Bold values indicate statistical significance at a $95 \%$ confidence level

Table 8. Mean $\delta^{13} \mathrm{C}$ and $\delta^{15} \mathrm{~N}$ values and $\pm \mathrm{SD}$ of all Halimeda spp., Dictoyta spp., and sponge on the first reef line

\begin{tabular}{|c|c|c|c|c|c|c|c|c|}
\hline \multirow[t]{2}{*}{ Site ID } & \multirow[t]{2}{*}{ Latitude $^{\circ} \mathrm{N}$} & \multirow[t]{2}{*}{ Longitude ${ }^{\circ} \mathrm{W}$} & \multirow{2}{*}{$\frac{\text { Halimeda sp. }}{\delta^{13} \mathrm{C}}$} & \multicolumn{3}{|c|}{ Dictoyta sp. } & \multicolumn{2}{|l|}{ Sponge } \\
\hline & & & & $\delta^{15} \mathrm{~N}$ & $\delta^{13} \mathrm{C}$ & $\delta^{15} \mathrm{~N}$ & $\delta^{13} \mathrm{C}$ & $\delta^{15} \mathrm{~N}$ \\
\hline $1 \mathrm{~A}$ & 26.0192 & -80.1026 & $-20.0 \pm 1.0$ & $4.9 \pm 0.3$ & $-15.3 \pm 0.0$ & $3.0 \pm 0.0$ & $-18.2 \pm 1.3$ & $6.5 \pm 0.9$ \\
\hline $2 \mathrm{~A}$ & 26.0160 & -80.0999 & $-20.2 \pm 0.0$ & $4.5 \pm 0.4$ & $-14.6 \pm 0.1$ & $4.0 \pm 0.2$ & $-17.5 \pm 0.2$ & $7.2 \pm 0.2$ \\
\hline $3 \mathrm{~A}$ & 26.0101 & -80.1021 & $-17.7 \pm 0.3$ & $4.3 \pm 0.4$ & $-16.5 \pm 1.3$ & $4.3 \pm 0.5$ & $-18.1 \pm 1.5$ & $7.9 \pm 0.4$ \\
\hline $4 \mathrm{~A}$ & 26.0038 & -80.1016 & $-20.3 \pm 0.0$ & $5.2 \pm 0.6$ & $-14.9 \pm 1.5$ & $4.5 \pm 0.1$ & $-18.5 \pm 1.5$ & $7.0 \pm 1.0$ \\
\hline $5 \mathrm{~A}$ & 25.9979 & -80.1021 & NM & $4.7 \pm 1.7$ & $-14.6 \pm 0.3$ & $4.3 \pm 0.1$ & $-19.0 \pm 0.0$ & $6.2 \pm 0.6$ \\
\hline $6 \mathrm{~A}$ & 25.9661 & -80.1011 & $-21.3 \pm 0.0$ & $4.8 \pm 0.1$ & $-16.1 \pm 0.0$ & $4.1 \pm 0.1$ & $-17.4 \pm 0.4$ & $7.5 \pm 0.3$ \\
\hline $7 \mathrm{~A}$ & 25.9290 & -80.1018 & NM & NM & $-14.6 \pm 1.3$ & $5.0 \pm 0.1$ & NM & NM \\
\hline $8 \mathrm{~A}$ & 25.9242 & -80.1001 & NM & NM & NM & NM & NM & NM \\
\hline $9 \mathrm{~A}$ & 25.9186 & -80.1010 & NM & NM & NM & NM & NM & NM \\
\hline $10 \mathrm{~A}$ & 25.9142 & -80.1010 & NM & $7.0 \pm 0.0$ & NM & $4.9 \pm 0.0$ & $-19.4 \pm 1.2$ & $5.1 \pm 0.5$ \\
\hline $11 \mathrm{~A}$ & NS & NS & NS & NS & NS & NS & NS & NS \\
\hline $12 \mathrm{~A}$ & 25.8978 & -80.1005 & NM & $4.6 \pm 0.5$ & NM & NM & NM & NM \\
\hline $13 \mathrm{~A}$ & 25.8934 & -80.1023 & NM & NM & NM & $4.7 \pm 0.3$ & NM & NM \\
\hline $14 \mathrm{~A}$ & 25.8865 & -80.1010 & NM & NM & NM & NM & NM & NM \\
\hline $15 \mathrm{~A}$ & 25.8804 & -80.1005 & NM & NM & NM & NM & NM & NM \\
\hline $16 \mathrm{~A}$ & 25.8657 & -80.0997 & NM & $5.2 \pm 0.4$ & NM & NM & $-18.4 \pm 1.0$ & $6.0 \pm 0.7$ \\
\hline $17 \mathrm{~A}$ & 25.8461 & -80.1040 & NM & $5.4 \pm 0.3$ & NM & NM & NM & NM \\
\hline $18 \mathrm{~A}$ & 25.8414 & -80.1031 & $-19.1 \pm 1.0$ & $4.3 \pm 0.4$ & $-15.9 \pm 1.3$ & $4.3 \pm 0.2$ & NM & $6.2 \pm 0.0$ \\
\hline $19 \mathrm{~A}$ & 25.8383 & -80.1005 & NM & NM & $-13.0 \pm 0.4$ & $4.7 \pm 0.4$ & NM & NM \\
\hline $20 \mathrm{~A}$ & 25.7997 & -80.0979 & NM & $5.1 \pm 0.1$ & $-12.6 \pm 0.2$ & $4.9 \pm 0.4$ & NM & NM \\
\hline $21 \mathrm{~A}$ & 25.7937 & -80.0971 & $-20.6 \pm 0.1$ & $4.7 \pm 0.4$ & $-13.9 \pm 0.0$ & $4.3 \pm 0.4$ & $-16.6 \pm 0.9$ & $5.7 \pm 0.2$ \\
\hline $22 \mathrm{~A}$ & NS & NS & NS & NS & NS & NS & NS & NS \\
\hline
\end{tabular}


Table 9. Mean $\delta^{13} \mathrm{C}$ and $\delta^{15} \mathrm{~N}$ values and $\pm \mathrm{SD}$ of all Halimeda spp., Dictoyta spp., and sponge on the second reef line

\begin{tabular}{|c|c|c|c|c|c|c|c|c|}
\hline \multirow[t]{2}{*}{ Site ID } & \multirow[t]{2}{*}{ Latitude $^{\circ} \mathrm{N}$} & \multirow[t]{2}{*}{ Longitude ${ }^{\circ} \mathrm{W}$} & \multirow{2}{*}{$\begin{array}{c}\text { Halimeda sp. } \\
\delta^{13} \mathrm{C}\end{array}$} & \multicolumn{3}{|c|}{ Dictoyta sp. } & \multicolumn{2}{|l|}{ Sponge } \\
\hline & & & & $\delta^{15} \mathrm{~N}$ & $\delta^{13} \mathrm{C}$ & $\delta^{15} \mathrm{~N}$ & $\delta^{13} \mathrm{C}$ & $\delta^{15} \mathrm{~N}$ \\
\hline 1B & NS & NS & $-21.5 \pm 0.0$ & $4.1 \pm 0.0$ & $-15.4 \pm 1.0$ & $3.0 \pm 0.5$ & $-18.6 \pm 0.0$ & $6.4 \pm 0.6$ \\
\hline $2 \mathrm{~B}$ & 26.0160 & -80.0957 & $-17.2 \pm 1.5$ & $6.3 \pm 0.6$ & $-14.9 \pm 0.3$ & $3.5 \pm 0.5$ & $-19.3 \pm 0.6$ & $4.7 \pm 0.3$ \\
\hline $3 \mathrm{~B}$ & 26.0096 & -80.0957 & $-21.8 \pm 0.0$ & $4.7 \pm 0.2$ & $-15.9 \pm 0.2$ & $4.3 \pm 0.2$ & $-19.8 \pm 1.4$ & $7.0 \pm 0.4$ \\
\hline $4 \mathrm{~B}$ & 26.0038 & -80.0968 & NM & $4.4 \pm 0.0$ & NM & $3.3 \pm 0.0$ & $-17.6 \pm 0.2$ & $6.1 \pm 0.1$ \\
\hline $5 \mathrm{~B}$ & NS & NS & NS & NS & NS & NS & NS & NS \\
\hline $6 \mathrm{~B}$ & 25.9656 & -80.0957 & NM & $3.7 \pm 1.0$ & NM & $5.7 \pm 0.2$ & NM & $7.8 \pm 0.0$ \\
\hline $7 \mathrm{~B}$ & 25.9285 & -80.0927 & $-17.4 \pm 0.0$ & $4.8 \pm 0.0$ & $-16.1 \pm 0.4$ & $4.0 \pm 0.2$ & $-17.7 \pm 0.1$ & $6.2 \pm 0.9$ \\
\hline $8 \mathrm{~B}$ & 25.9238 & -80.0931 & NM & NM & NM & NM & NM & $5.1 \pm 0.3$ \\
\hline $9 \mathrm{~B}$ & 25.9164 & -80.0910 & NM & $4.7 \pm 0.1$ & NM & $4.7 \pm 0.0$ & NM & NM \\
\hline $10 \mathrm{~B}$ & 25.9138 & -80.0927 & $-17.7 \pm 1.4$ & $4.4 \pm 0.1$ & $-15.1 \pm 0.0$ & $4.2 \pm 0.1$ & $-19.0 \pm 1.3$ & $6.3 \pm 1.3$ \\
\hline 11B & 25.9060 & -80.0962 & $-16.1 \pm 0.0$ & $4.5 \pm 0.0$ & NM & $6.2 \pm 0.3$ & NM & NM \\
\hline $12 \mathrm{~B}$ & 25.8978 & 80.0931 & $\mathrm{NM}$ & $4.2 \pm 0.9$ & NM & $\mathrm{NM}$ & NM & NM \\
\hline 13B & 25.8934 & -80.0953 & NM & $6.5 \pm 0.3$ & NM & NM & NM & NM \\
\hline 14B & 25.8878 & -80.0966 & NM & NM & NM & NM & NM & NM \\
\hline 15B & 25.8817 & -80.0962 & NM & NM & NM & NM & NM & NM \\
\hline $16 \mathrm{~B}$ & 25.8657 & -80.0923 & $-21.6 \pm 1.0$ & $3.7 \pm 0.5$ & NM & NM & NM & NM \\
\hline 17B & 25.8453 & -80.0957 & NM & NM & NM & NM & NM & NM \\
\hline $18 \mathrm{~B}$ & NS & NS & NS & NS & NS & NS & NS & NS \\
\hline 19B & 25.8379 & -80.0931 & $-20.5 \pm 2.0$ & $4.7 \pm 0.4$ & $-13.7 \pm 0.1$ & $4.1 \pm 0.1$ & $-20.1 \pm 0.0$ & $6.3 \pm 0.0$ \\
\hline $20 \mathrm{~B}$ & 25.8002 & -80.0923 & $-24.4 \pm 0.0$ & $4.7 \pm 0.0$ & $-14.9 \pm 0.3$ & $4.5 \pm 0.7$ & $-19.6 \pm 0.0$ & $5.8 \pm 2.0$ \\
\hline $21 \mathrm{~B}$ & 25.7937 & -80.0918 & $-20.8 \pm 0.0$ & $4.5 \pm 0.1$ & NM & $4.9 \pm 0.0$ & $-18.1 \pm 0.1$ & $4.8 \pm 0.4$ \\
\hline $22 \mathrm{~B}$ & NS & NS & NS & NS & NS & NS & NS & NS \\
\hline
\end{tabular}

$\mathrm{NM}=$ site not measured, $\mathrm{NS}=$ not sampled at that site 
Table 10. Mean $\delta^{13} \mathrm{C}$ and $\delta^{15} \mathrm{~N}$ values and $\pm \mathrm{SD}$ of all Halimeda spp., Dictoyta spp., and sponge on the third reef line

\begin{tabular}{|c|c|c|c|c|c|c|c|c|}
\hline \multirow[t]{2}{*}{ Site ID } & \multirow[t]{2}{*}{ Latitude $^{\circ} \mathrm{N}$} & \multirow[t]{2}{*}{ Longitude ${ }^{\circ} \mathrm{W}$} & \multicolumn{2}{|l|}{ Halimeda sp. } & \multicolumn{2}{|l|}{ Dictoyta sp. } & \multicolumn{2}{|l|}{ Sponge } \\
\hline & & & $\delta^{13} \mathrm{C}$ & $\delta^{15} \mathrm{~N}$ & $\delta^{13} \mathrm{C}$ & $\delta^{15} \mathrm{~N}$ & $\delta^{13} \mathrm{C}$ & $\delta^{15} \mathrm{~N}$ \\
\hline $1 \mathrm{C}$ & NS & NS & NS & NS & $-16.9 \pm 2.0$ & $3.3 \pm 0.3$ & $-19.0 \pm 0.9$ & $5.6 \pm 0.9$ \\
\hline $2 \mathrm{C}$ & 26.0160 & -80.0878 & $-19.3 \pm 0.0$ & $4.2 \pm 0.5$ & $-17.4 \pm 0.6$ & $4.4 \pm 0.4$ & $-19.3 \pm 0.6$ & $6.5 \pm 0.5$ \\
\hline $3 \mathrm{C}$ & 26.0096 & -80.0883 & $-17.5 \pm 0.0$ & $4.1 \pm 0.8$ & $-15.8 \pm 0.0$ & $4.1 \pm 0.0$ & $-17.9 \pm 0.2$ & $6.7 \pm 0.6$ \\
\hline $4 \mathrm{C}$ & 26.0032 & -80.0889 & NM & $3.0 \pm 0.0$ & $-13.8 \pm 1.6$ & $4.2 \pm 0.1$ & NM & NM \\
\hline $5 \mathrm{C}$ & NS & NS & NS & NS & NS & NS & NS & NS \\
\hline $6 \mathrm{C}$ & 25.9661 & -80.0899 & $-18.6 \pm 2.5$ & $6.0 \pm 0.0$ & NM & NM & $-19.1 \pm 0.1$ & $4.4 \pm 0.1$ \\
\hline $7 \mathrm{C}$ & 25.9299 & -80.0892 & $-16.6 \pm 1.3$ & $5.2 \pm 0.8$ & $-13.7 \pm 1.6$ & $4.4 \pm 0.1$ & $-17.4 \pm 0.0$ & $7.0 \pm 0.1$ \\
\hline $8 \mathrm{C}$ & 25.9242 & -80.0888 & NM & NM & NM & NM & NM & NM \\
\hline $9 \mathrm{C}$ & 25.9181 & -80.0879 & NM & NM & $-17.3 \pm 0.0$ & $3.9 \pm 0.0$ & NM & NM \\
\hline $10 \mathrm{C}$ & 25.9134 & -80.0884 & $-19.2 \pm 1.6$ & $3.9 \pm 0.2$ & $-10.8 \pm 0.0$ & $3.1 \pm 0.0$ & NM & NM \\
\hline $11 \mathrm{C}$ & 25.9056 & -80.0884 & NM & $4.9 \pm 0.0$ & NM & NM & NM & NM \\
\hline $12 \mathrm{C}$ & 25.8982 & -80.0879 & NM & $3.2 \pm 0.6$ & NM & $2.7 \pm 0.2$ & NM & NM \\
\hline $13 \mathrm{C}$ & 25.8930 & -80.0892 & NM & $4.3 \pm 0.8$ & NM & $4.5 \pm 0.7$ & NM & NM \\
\hline $14 \mathrm{C}$ & 25.8878 & -80.0897 & NM & NM & NM & NM & NM & NM \\
\hline $15 \mathrm{C}$ & 25.8813 & -80.0879 & NM & $2.7 \pm 0.0$ & $-16.1 \pm 1.4$ & $4.2 \pm 0.3$ & NM & NM \\
\hline $16 \mathrm{C}$ & 25.8657 & -80.0884 & $-19.6 \pm 0.0$ & $4.1 \pm 0.8$ & NM & NM & $-19.5 \pm 1.0$ & $6.7 \pm 0.8$ \\
\hline $17 \mathrm{C}$ & 25.8453 & -80.0884 & NM & NM & NM & NM & $\mathrm{NM}$ & $\mathrm{NM}$ \\
\hline $18 \mathrm{C}$ & NS & NS & NM & NM & NM & NM & NM & NM \\
\hline $19 \mathrm{C}$ & 25.8383 & -80.0888 & $-19.1 \pm 1.6$ & $3.6 \pm 0.4$ & NM & NM & $-18.0 \pm 0.9$ & $5.1 \pm 1.0$ \\
\hline $20 \mathrm{C}$ & 25.8002 & -80.0875 & $\mathrm{NM}$ & $2.8 \pm 0.0$ & NM & NM & $-20.1 \pm 0.0$ & $3.8 \pm 0.1$ \\
\hline $21 \mathrm{C}$ & 25.7945 & -80.0884 & NS & NS & NS & NS & NS & NS \\
\hline $22 \mathrm{C}$ & 25.7850 & -80.0888 & $-21.4 \pm 0.0$ & $5.3 \pm 0.4$ & NM & NM & $-17.6 \pm 1.1$ & $4.6 \pm 1.3$ \\
\hline
\end{tabular}

$\mathrm{NM}=$ site not measured, $\mathrm{NS}=$ not sampled at that site 
Table 11. Principle Component Analysis of benthic characteristics

35 percent of variability explained by Factor 1 and 2 .

Squared cosines of the variables:

\begin{tabular}{lll}
\hline & F1 & F2 \\
\hline Hard relief $(\mathrm{m})$ & $\mathbf{0 . 2 4 5}$ & 0.011 \\
Soft relief $(\mathrm{m})$ & 0.060 & 0.157 \\
Sand \% & 0.046 & $\mathbf{0 . 2 9 7}$ \\
Bare \% & 0.000 & 0.129 \\
S Macroalgae \% & 0.095 & $\mathbf{0 . 4 0 1}$ \\
S Sponge \% & $\mathbf{0 . 3 7 3}$ & 0.373 \\
Rubble \% & 0.193 & 0.000 \\
Hard bottom \% & 0.012 & 0.081 \\
Live coral \% & 0.086 & $\mathbf{0 . 3 2 1}$ \\
H Algae $<1 \%$ & $\mathbf{0 . 4 8 6}$ & 0.106 \\
H Algae $>1 \%$ & 0.016 & $\mathbf{0 . 2 7 0}$ \\
H Octocorals \% & $\mathbf{0 . 6 1 7}$ & 0.000 \\
H Sponge \% & $\mathbf{0 . 6 0 7}$ & 0.003 \\
Depth $(\mathrm{m})$ & 0.005 & 0.028 \\
Visibility $(\mathrm{m})$ & $\mathbf{0 . 3 2 9}$ & 0.036 \\
Temperature $\left({ }^{\circ} \mathrm{C}\right)$ & 0.150 & $\mathbf{0 . 2 8 5}$ \\
\hline
\end{tabular}

Table 12. Baseline values of $\delta^{13} \mathrm{C}$ and $\delta^{15} \mathrm{~N}$ values for biota in this study

\begin{tabular}{llccc}
\hline Reference & Location & Species & $\delta^{15} \mathrm{~N}$ & $\delta^{13} \mathrm{C}$ \\
\hline Lamb et al. (2012) & Upper Florida Keys, SE Florida & Halimeda & 1.6 & -17.0 \\
& & Dictoyta & 2.4 & -16.5 \\
& & Sponge & 4.2 & -17.2 \\
Anderson et al. (2010) & Broward County & Dictoyta & 3.5 & -15 \\
Cocheret de la Moriniere et al. (2003) & Curacao, Netherlands & Halimeda & 1.5 & -18.5 \\
& & Dictoyta & 1.8 & -17.5 \\
Hitling et al. (2013) & Papahanumokukea, Hawai & Halimeda & 1.1 & -20.1 \\
\hline
\end{tabular}




\section{FIGURES}

\section{Increased nutrients \&/or sediments}

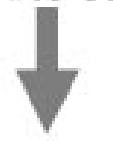

Increased algal growth (rates)

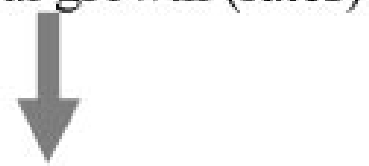

Increased algal abundance

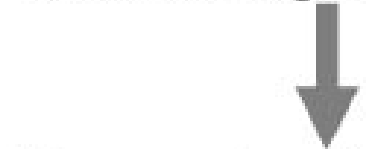

Decreased coral abundance

Figure 1. Conceptual model of bottom up control of nutrient enrichment and the potential trophic cascading in a coral reef ecosystem (McCook, 1999) 


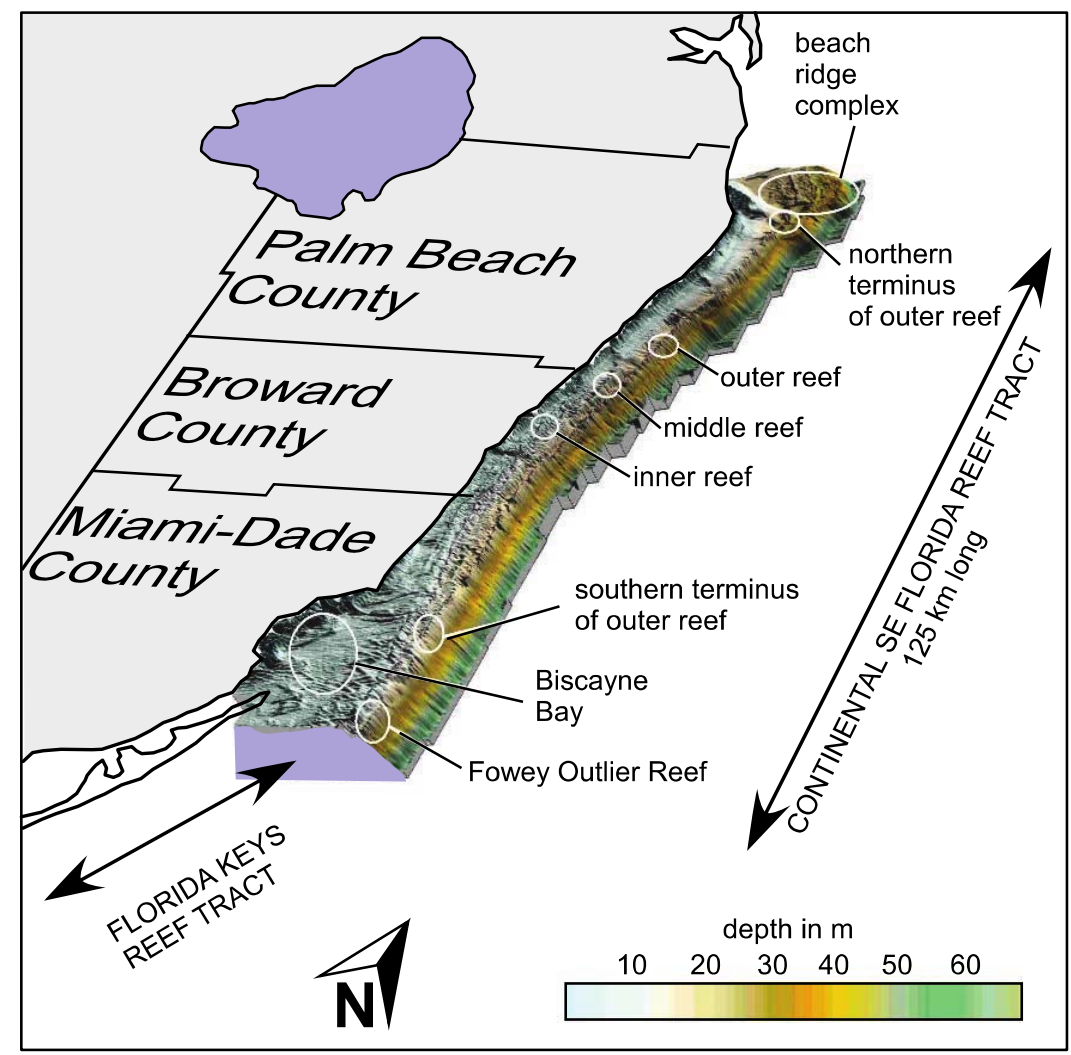

Figure 2. Continental Southeast Florida Reef Tract (Banks et al., 2008) 


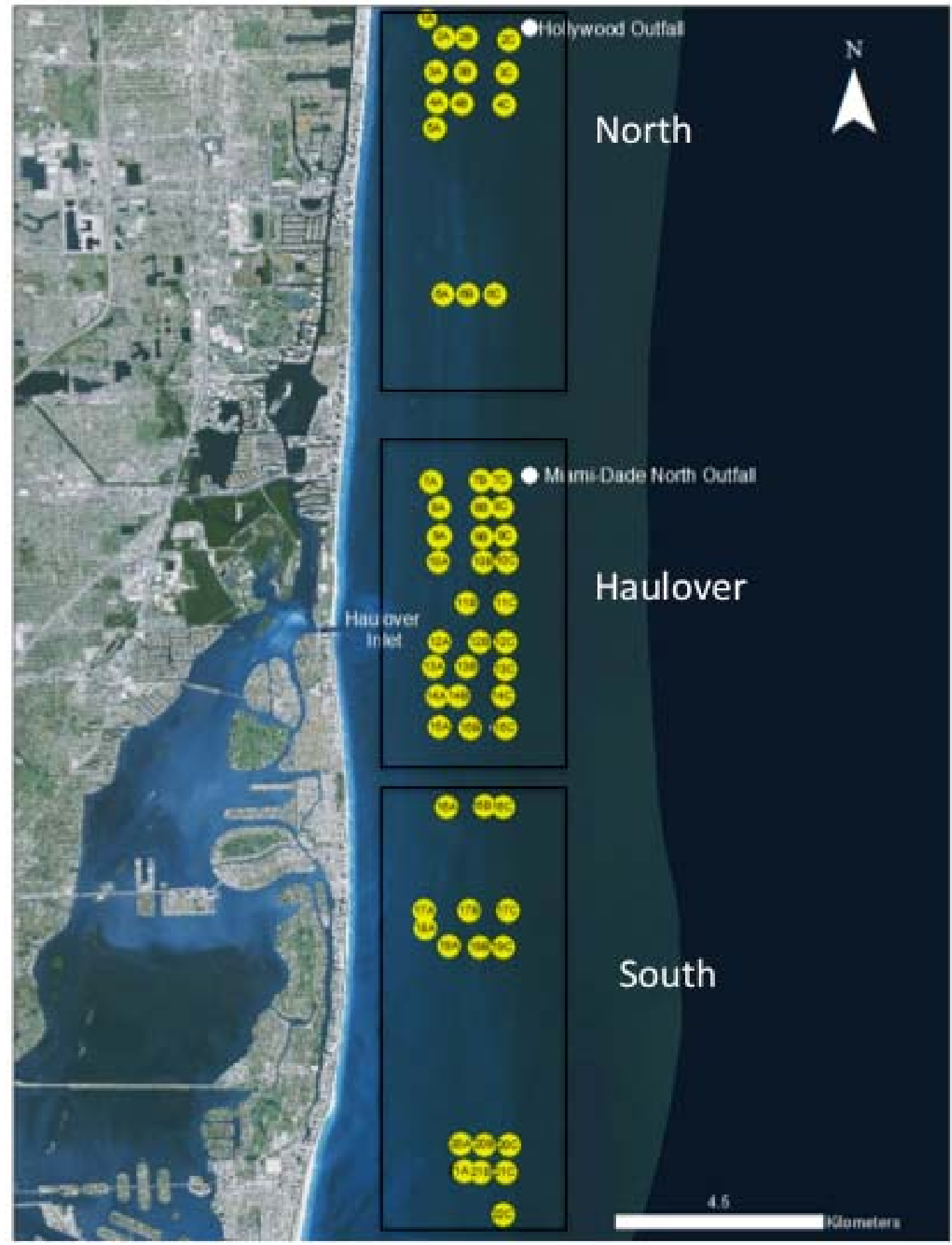

Figure 3. Florida Reef Tract dive sites (GIS World Imagery layer)

Sites are broken down by region North, Haulover, and South. Sites labeled A, B, and C are located on the first reef line, second, and third reef line, respectfully. 


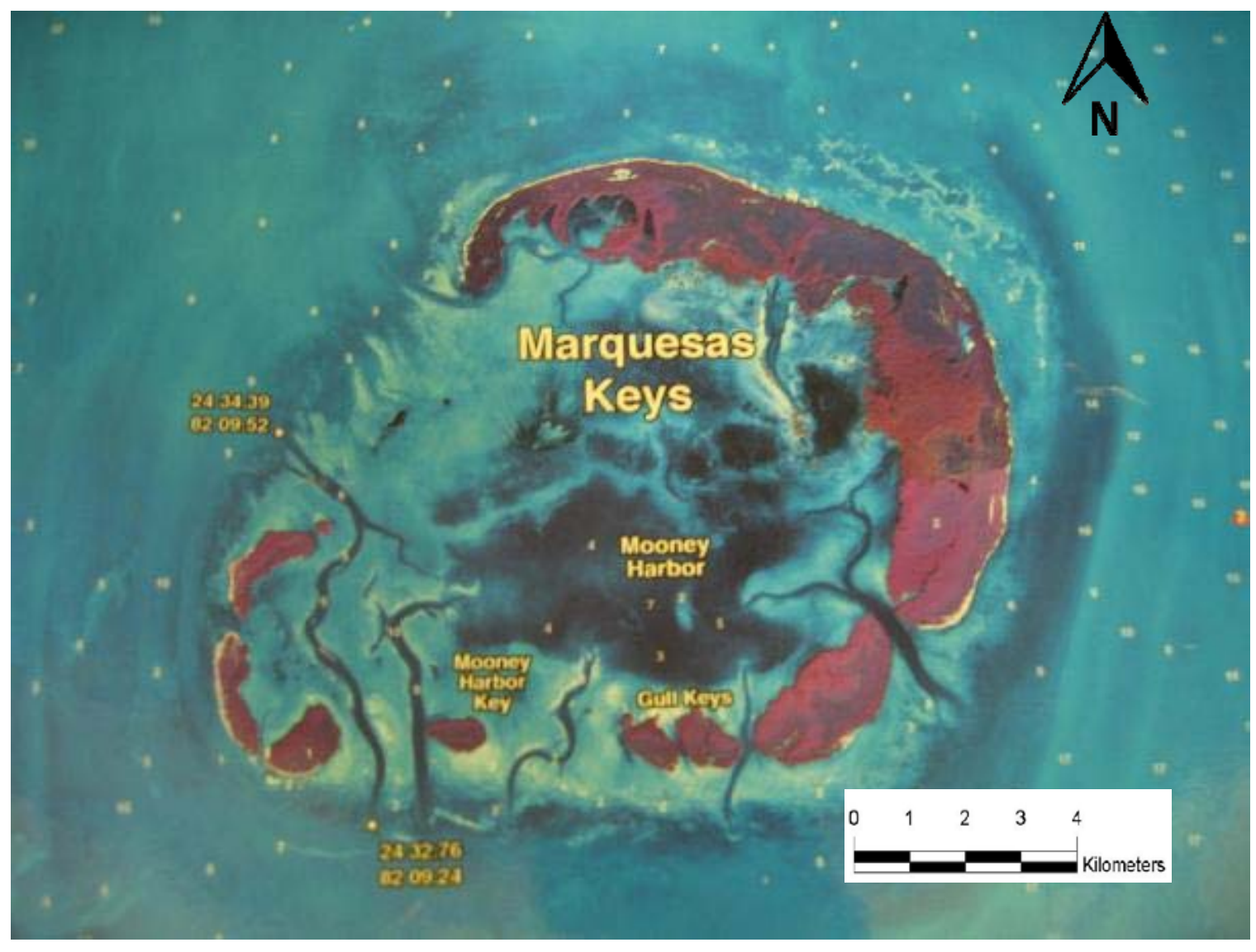

Figure 4. Marquesas Keys map

(http://www.brucechard.com/home/satellitelowerkeyscharts.html) 


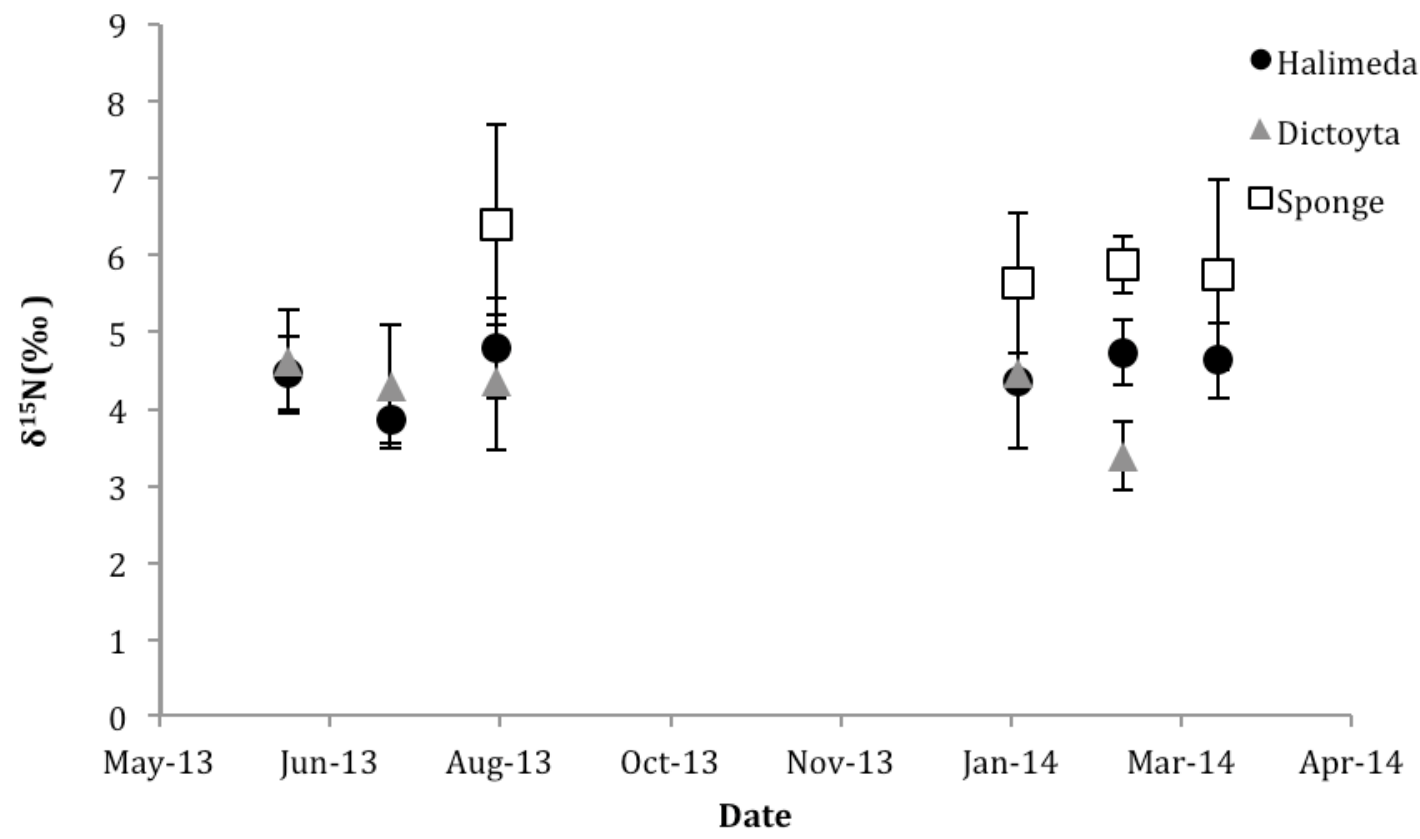

Figure 5. Mean $\delta^{15} \mathrm{~N}$ values of all three biota groups over the sampling period displaying temporal variability

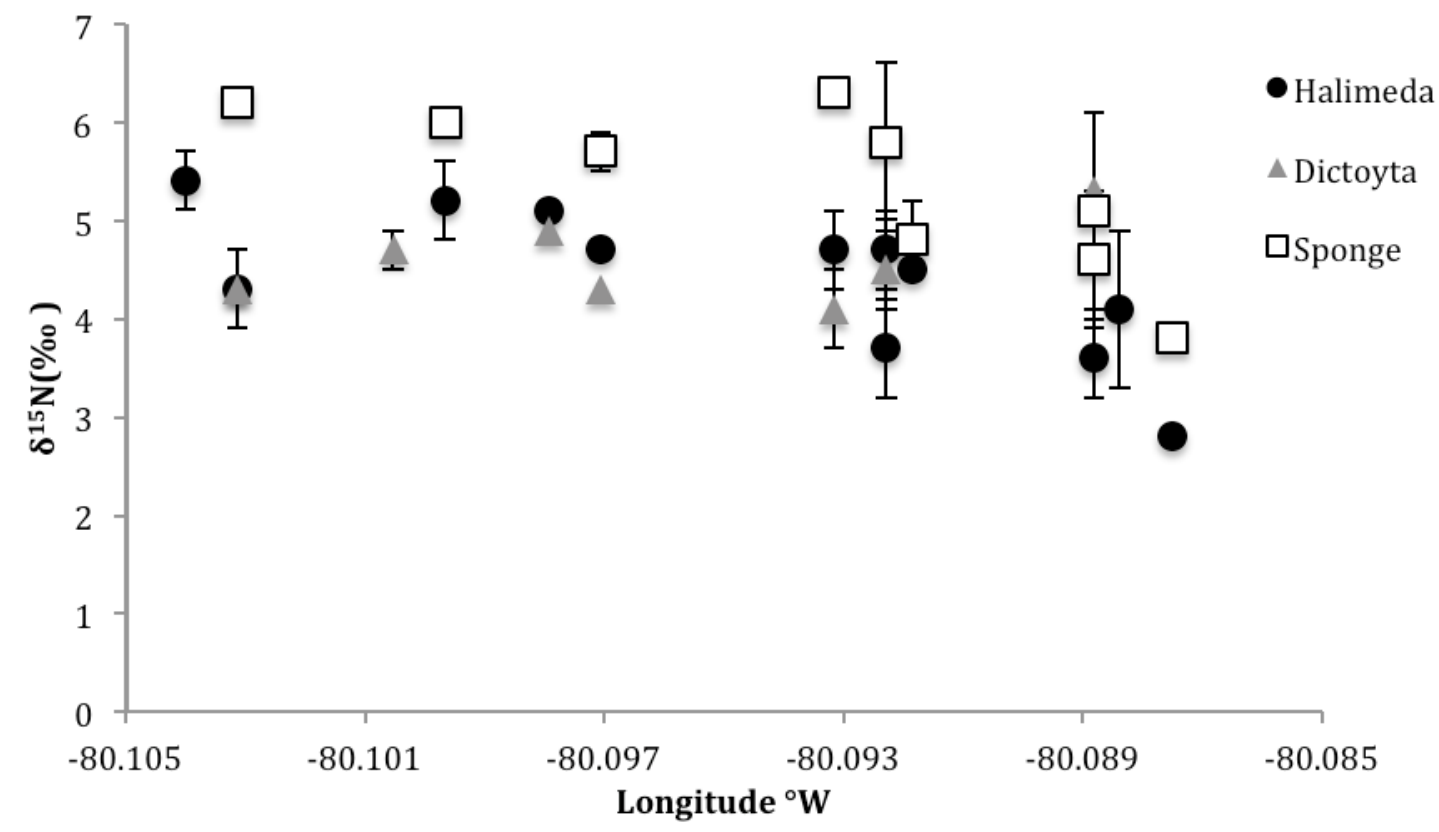

Figure $6 . \delta^{15} \mathrm{~N}$ data of Halimeda spp., Dictoyta spp., and sponge samples collected at the South sites plotted against longitude

Error bars represent \pm SD. 


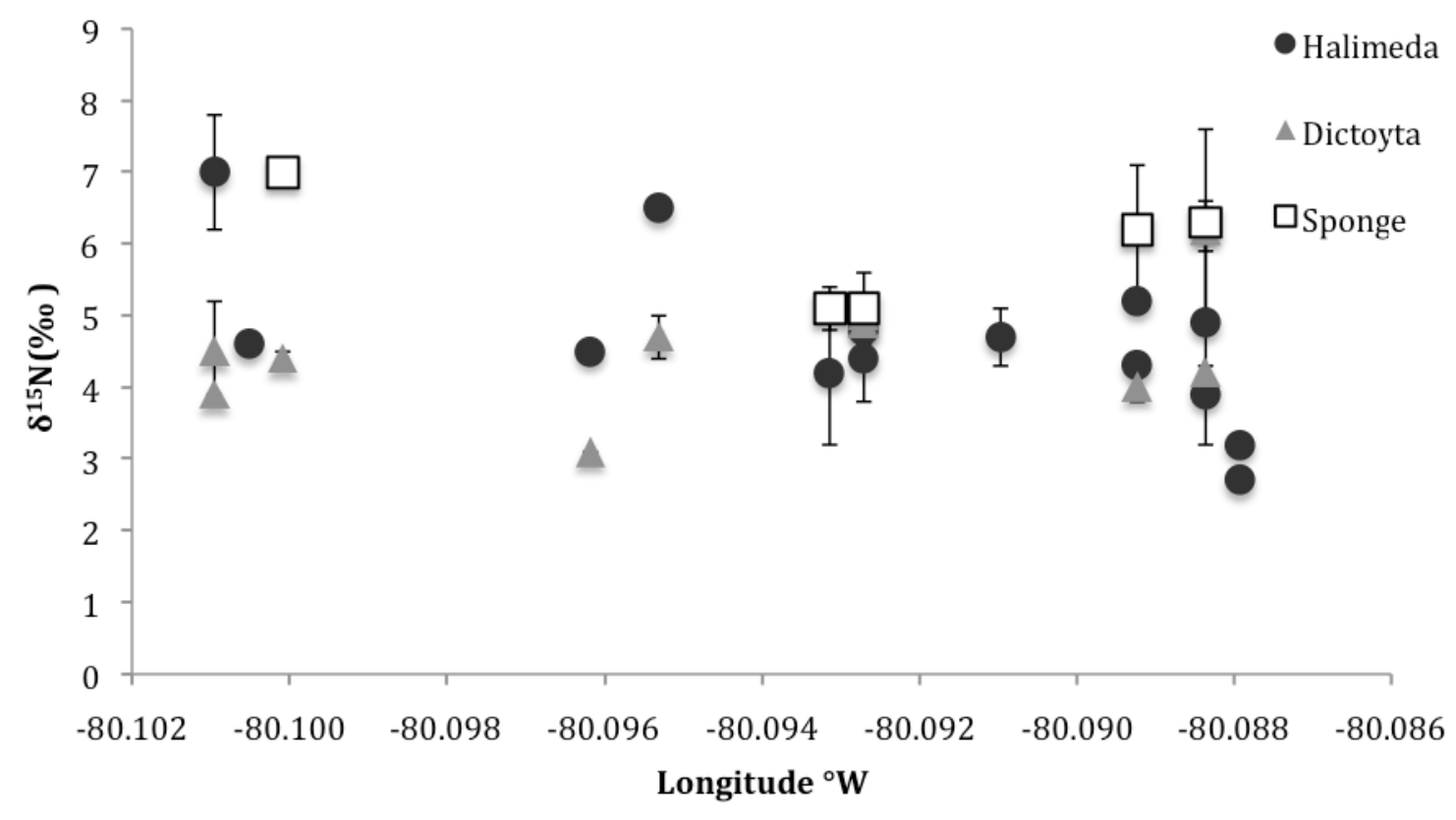

Figure 7. $\delta^{15} \mathrm{~N}$ data of Halimeda spp., Dictoyta spp., and sponge samples collected at the Haulover sites plotted against longitude

Error bars represent $\pm \mathrm{SD}$. 


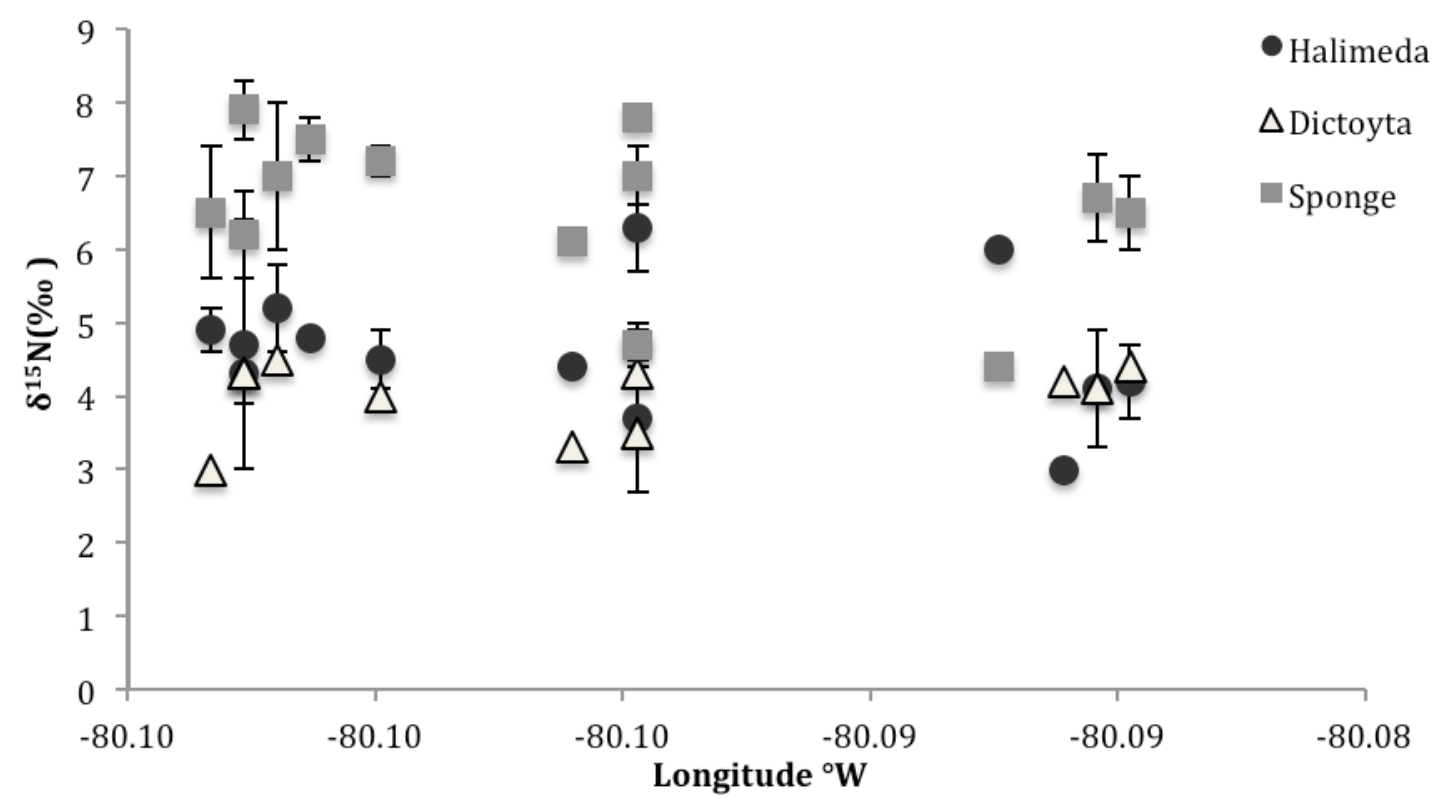

Figure 8. $\delta^{15} \mathrm{~N}$ data of Halimeda spp., Dictoyta spp., and sponge samples collected at the North sites plotted against longitude

Error bars represent $\pm \mathrm{SD}$. 


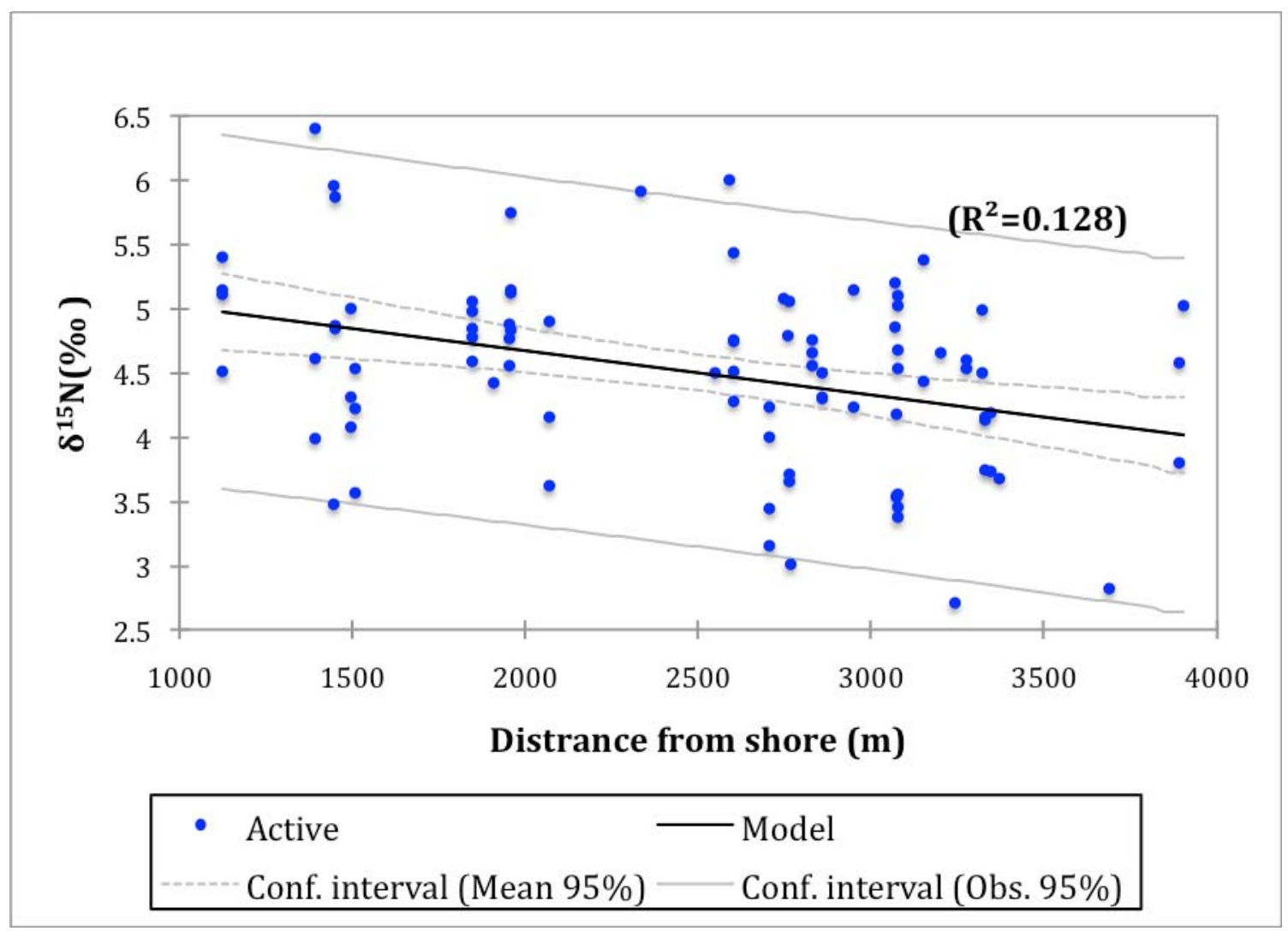

Figure 9. Linear regression of $\delta^{15} \mathrm{~N}$ values for Halimeda spp. by distance from shore 


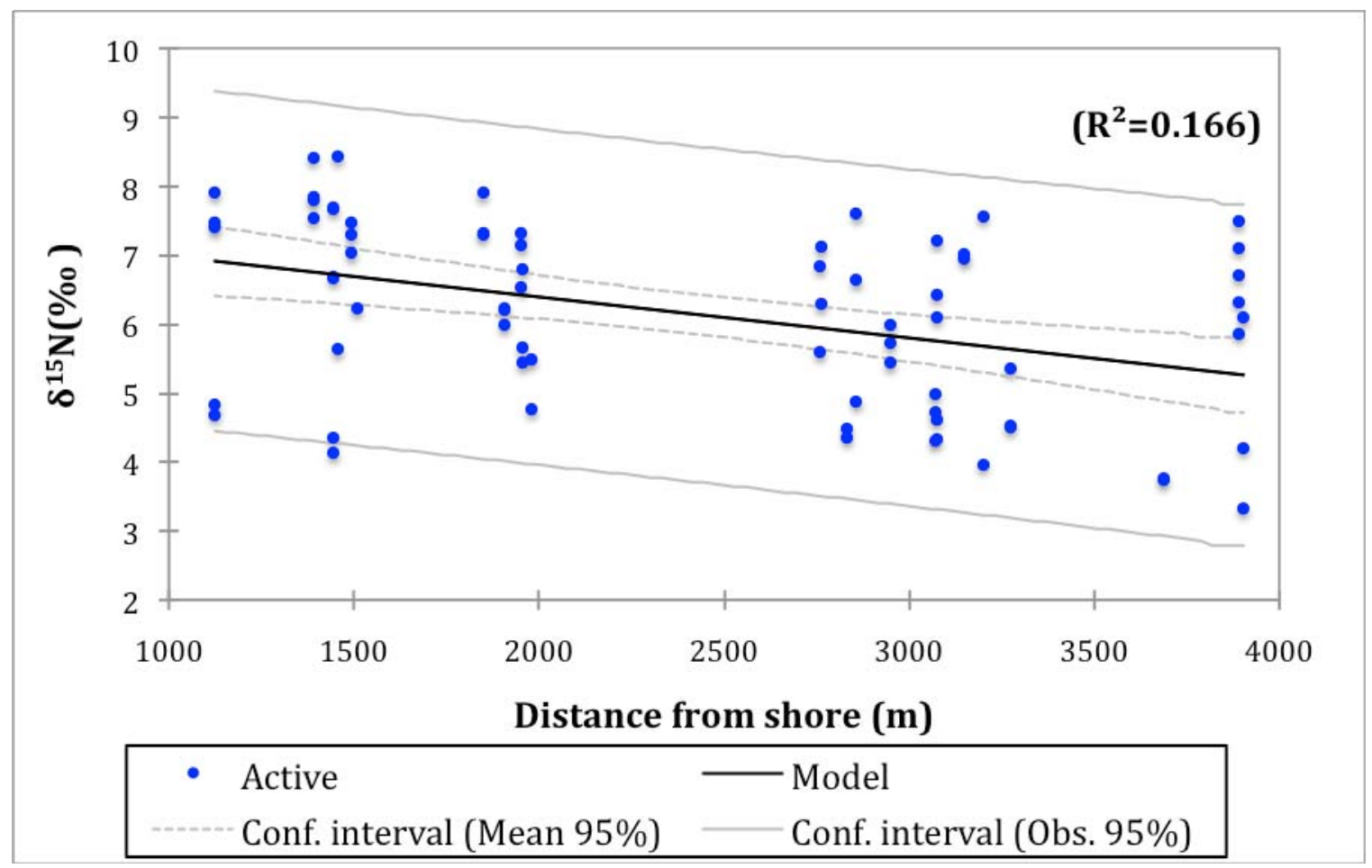

Figure 10. Linear regression of $\delta^{15} \mathrm{~N}$ values for sponges by distance from shore 


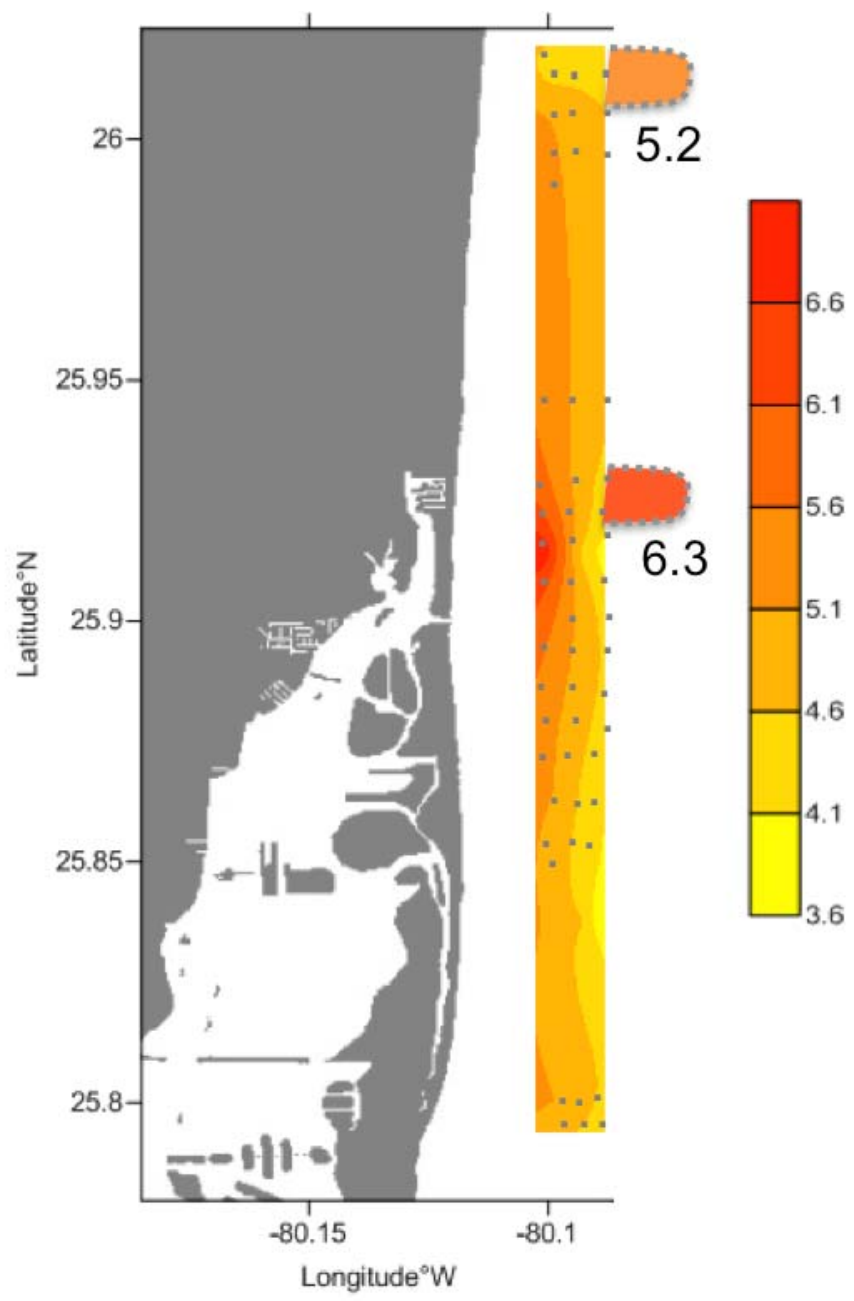

Figure 11. Mean $\delta^{15} \mathrm{~N}$ of Halimeda spp. across the sampling region

Data points located within 1000 meters of an outfall were excluded to show the natural isotopic depletion West to East. Dotted grey line represents the sites that are within 1000 meters and the value next to the section is the mean $\delta^{15} \mathrm{~N}$ value of Halimeda spp. in this area. Grey dots represent dive sites sampled for Halimeda spp. 


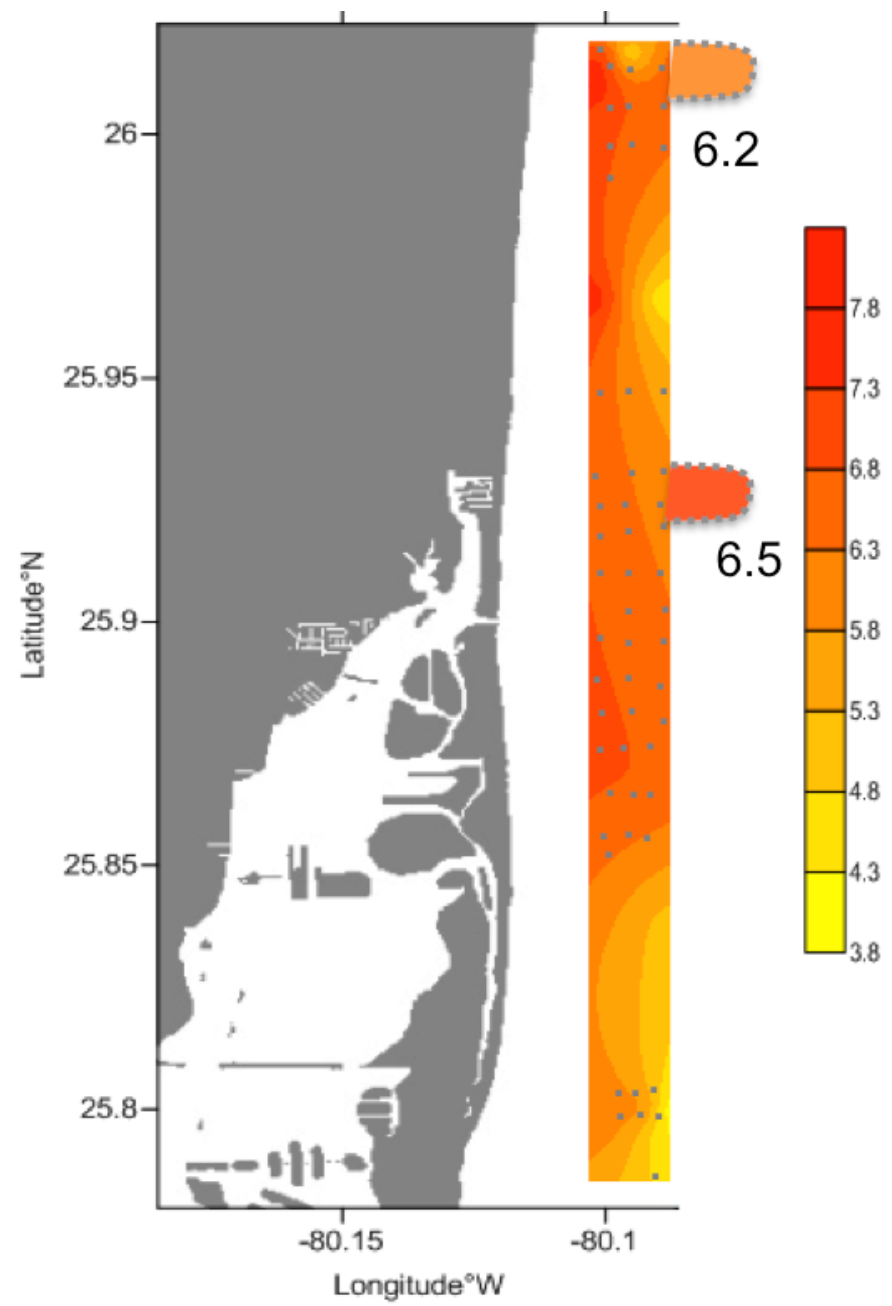

Figure 12. Mean $\delta^{15} \mathrm{~N}$ of sponge across the sampling region

Data points located within 1000 meters of an outfall were excluded to show the natural isotopic depletion West to East. Dotted grey line represents the sites that are within 1000 meters and the value next to the section is the mean $\delta^{15} \mathrm{~N}$ value of sponges in this area. Grey dots represent dive sites sampled for sponges. 


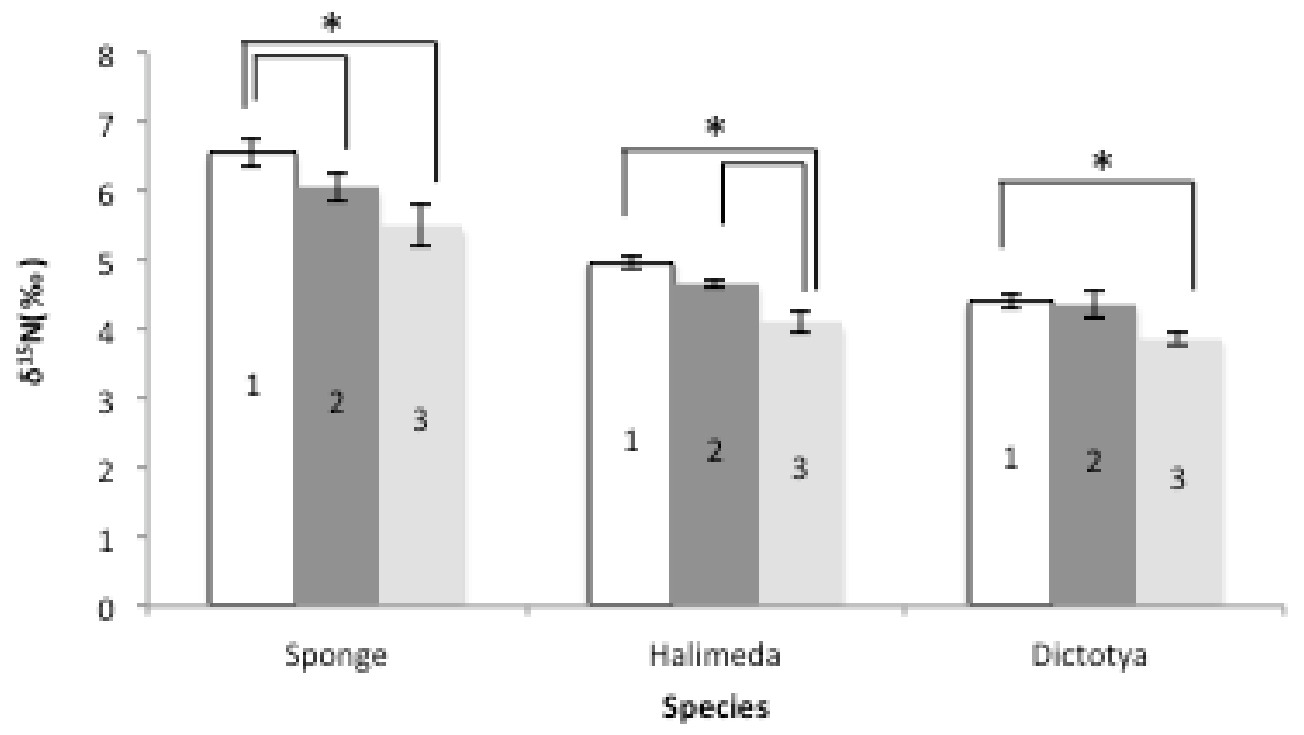

Figure 13. Mean $\delta^{15} \mathrm{~N}$ data of Halimeda spp., Dictoyta spp., and sponge samples collected at all sites along the three reef lines

Mann-Whitney $U$ test for reef line comparison of $\delta^{15} \mathrm{~N}$. Brackets indicate and asterisk indicate $\mathrm{p}$ values $<0.05$. Error bars reflect the standard error of the mean. 


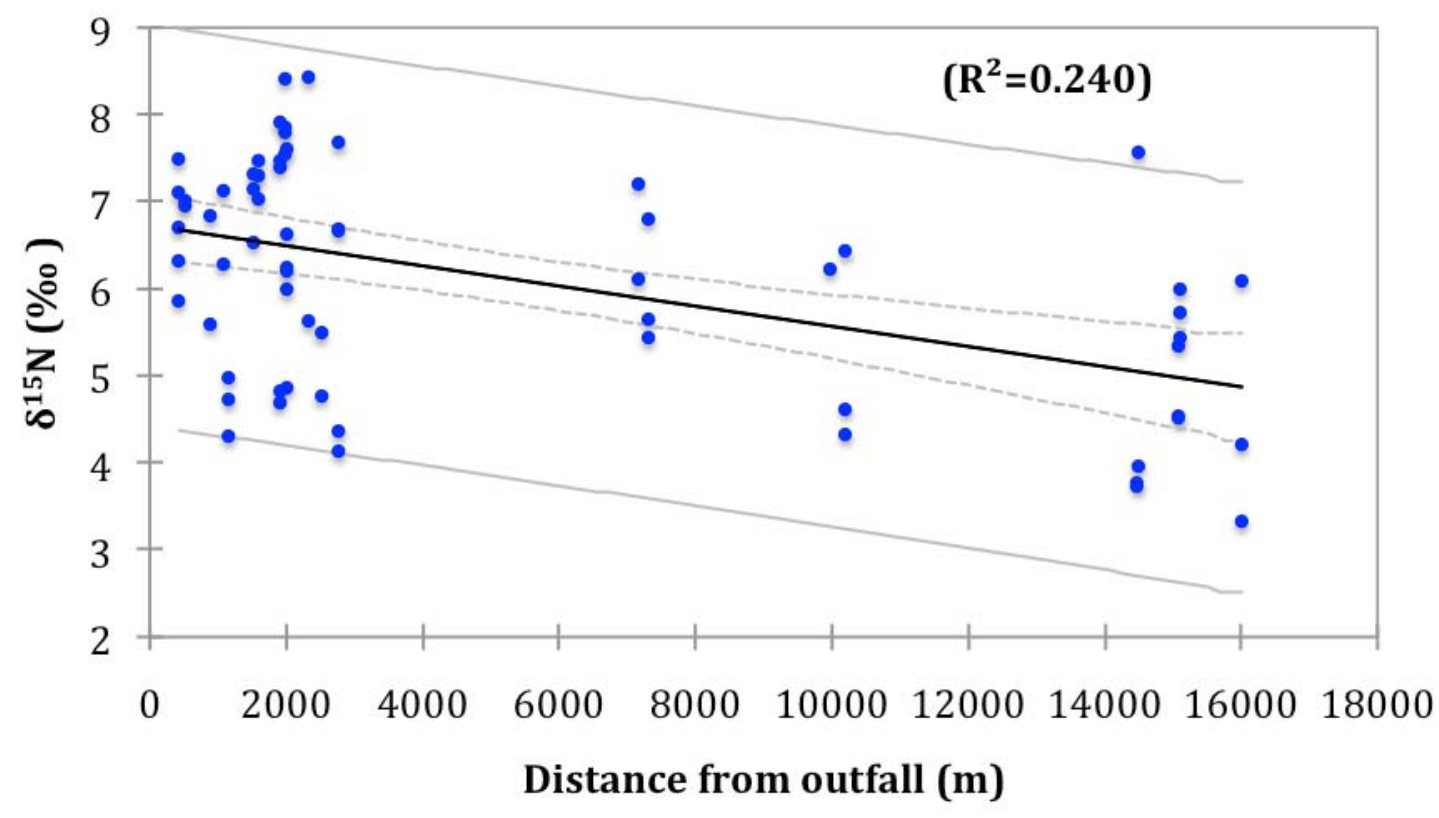

- Active

Model

Conf. interval (Mean 95\%)

Conf. interval (Obs. 95\%)

Figure 14. Linear regression of $\delta^{15} \mathrm{~N}$ values for sponges by distance from outfall 


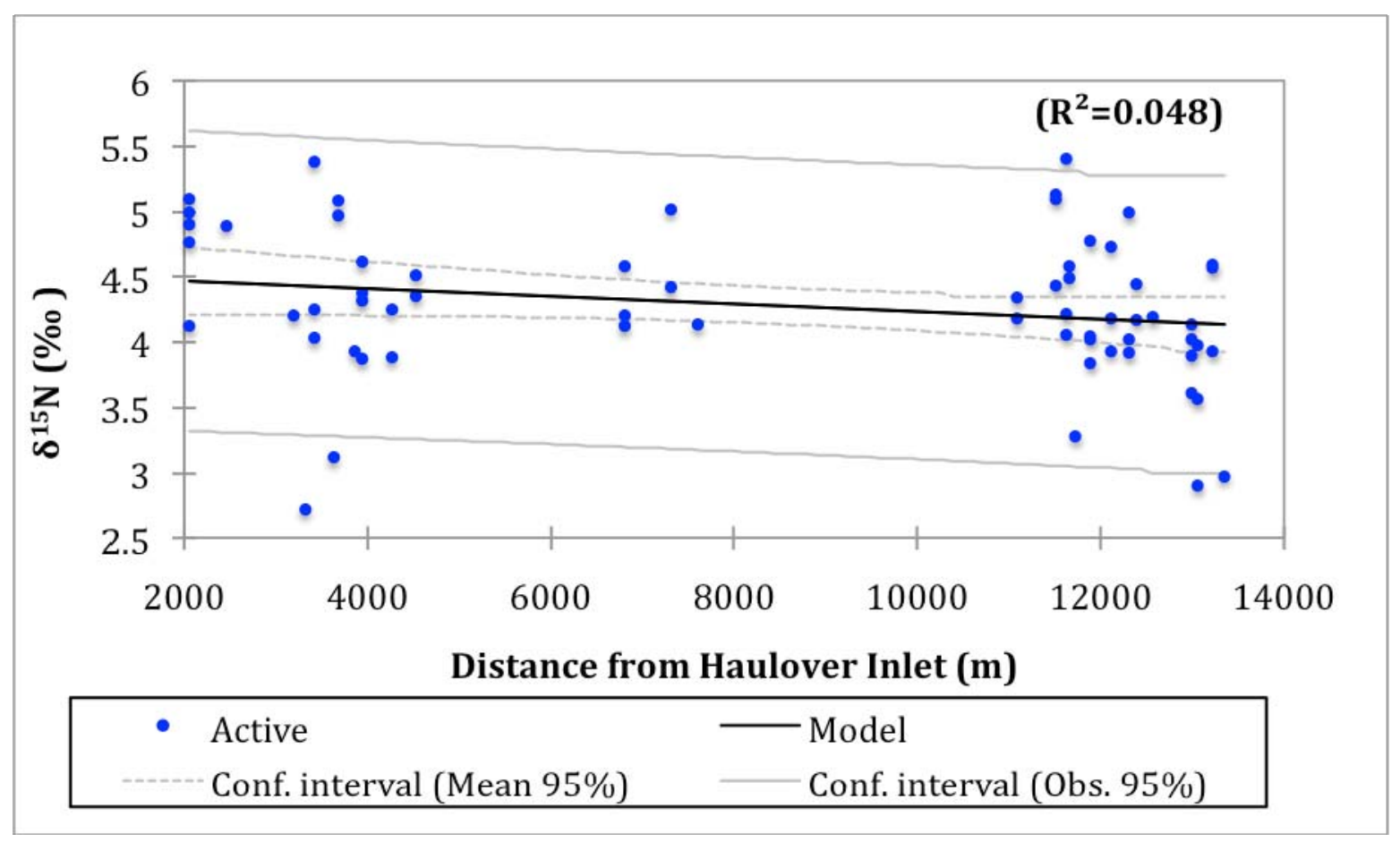

Figure 15. Linear regression of $\delta^{15} \mathrm{~N}$ values for Dictoyta spp. by distance from Haulover Inlet 


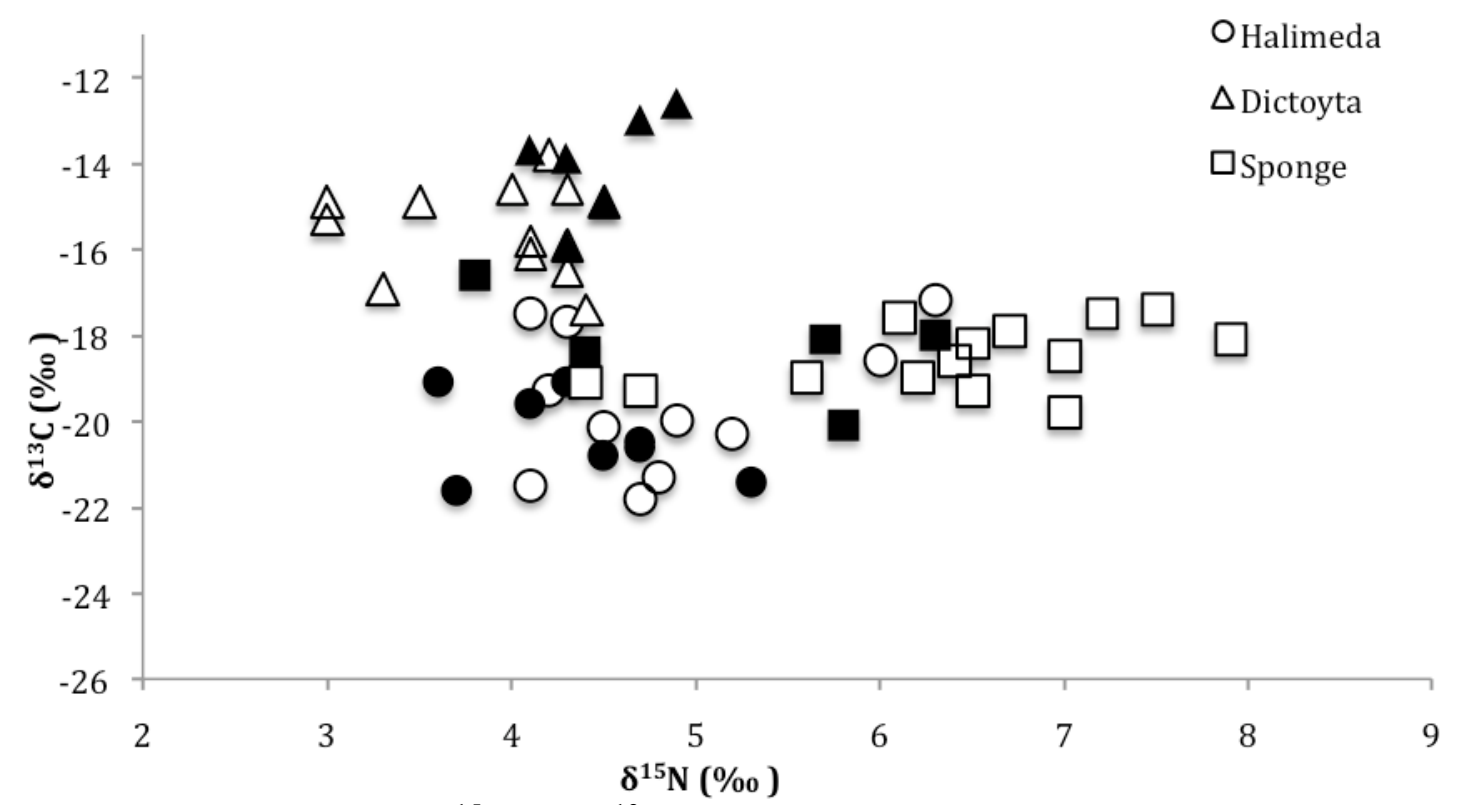

Figure 16. Comparison of $\delta^{15} \mathrm{~N}$ and $\delta^{13} \mathrm{C}$ data for the North and South sites

North sites, which are found adjacent to Hollywood outfall (unfilled symbols) compared to the South sites (shaded in symbols), these sites are not located next to a point source. 


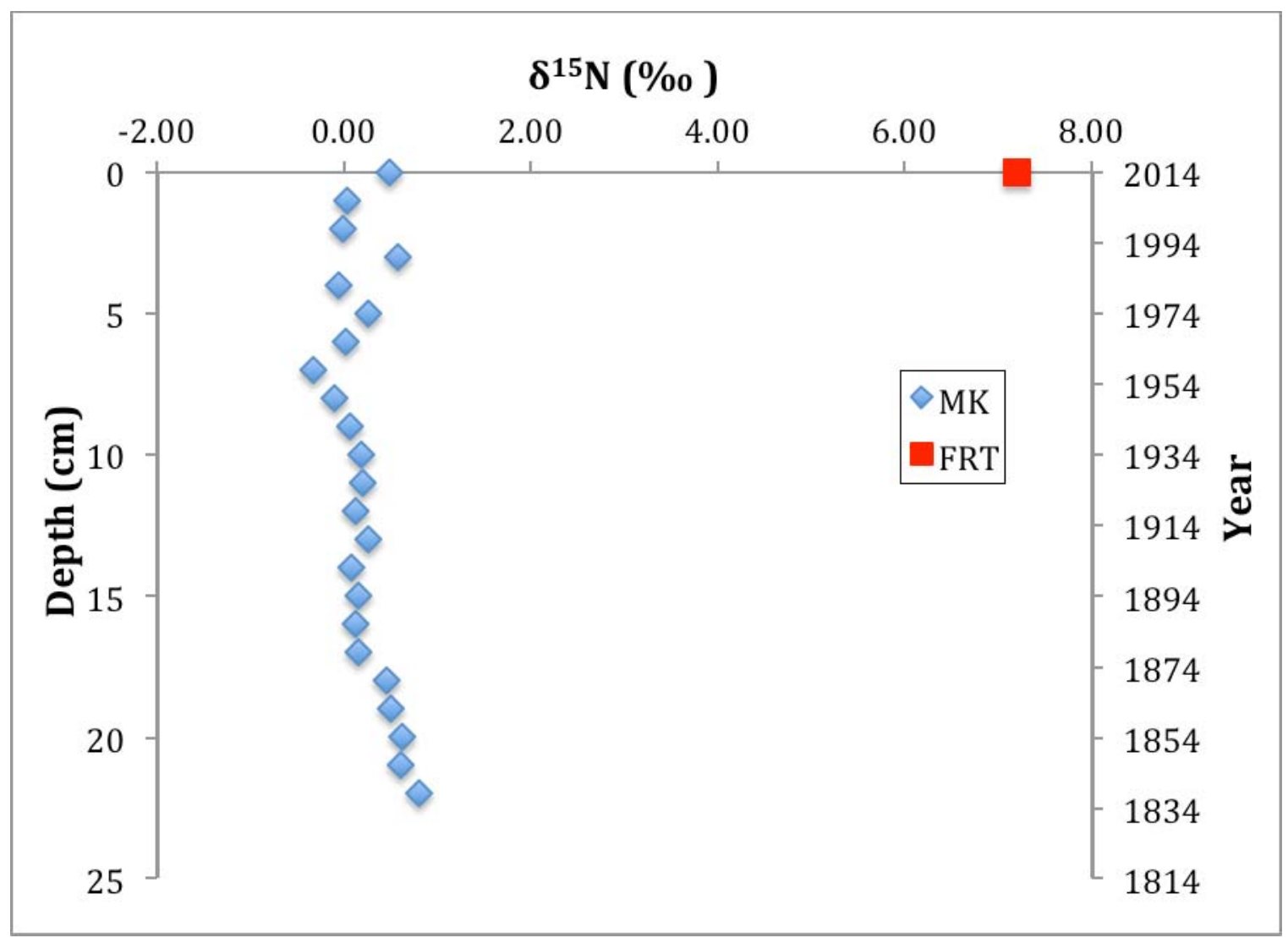

Figure 17. Marquesas Keys core dated using ${ }^{210} \mathrm{~Pb}$ and Florida Reef Tract sediment $\delta^{15} \mathrm{~N}$ values 


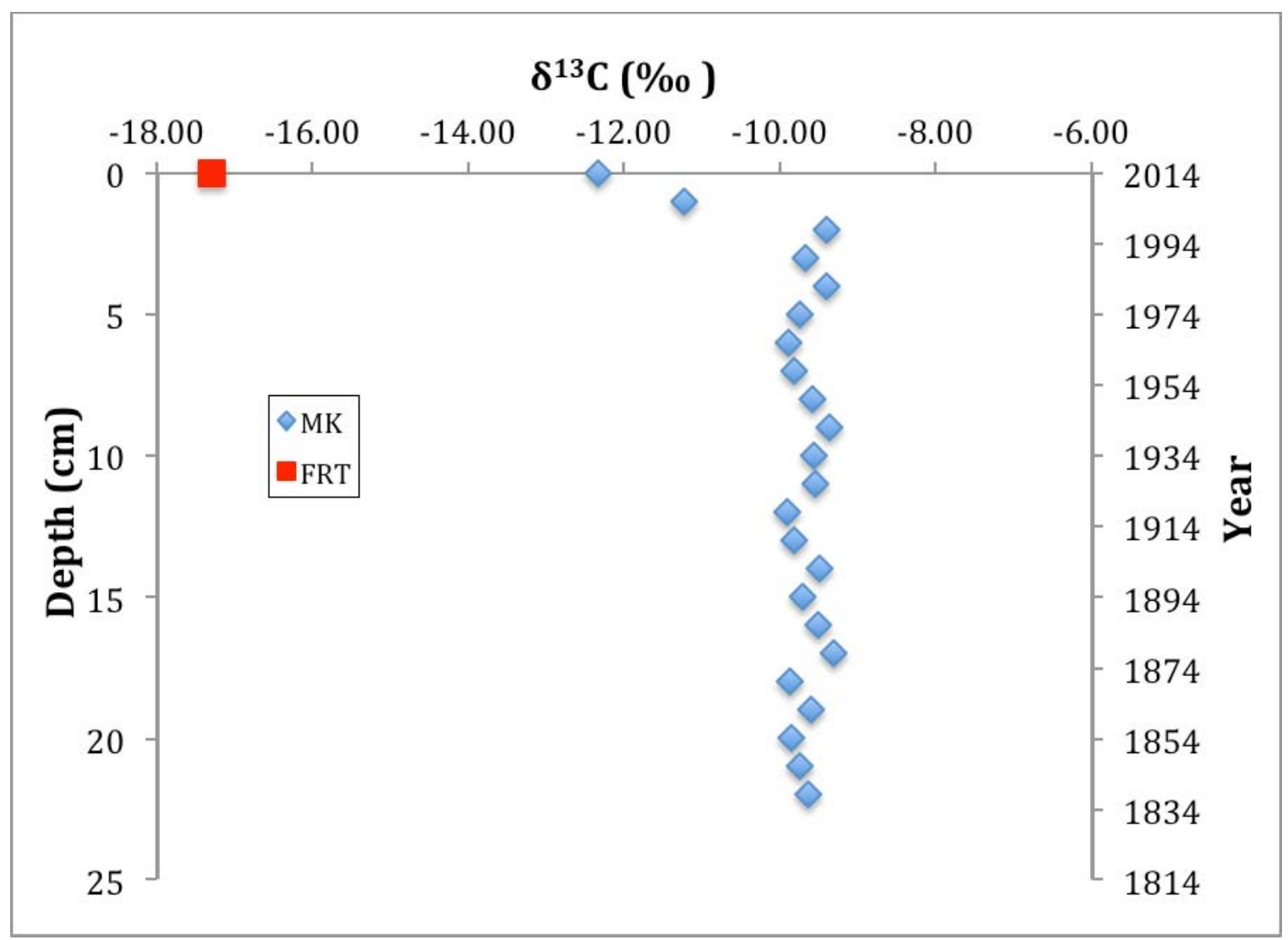

Figure 18. Marquesas Keys core $\delta^{13} \mathrm{C}$ values dated using ${ }^{210} \mathrm{~Pb}$ with upper $\mathrm{cm}$ mean $\delta^{13} \mathrm{C}$ value for Florida Reef Tract sediment. 


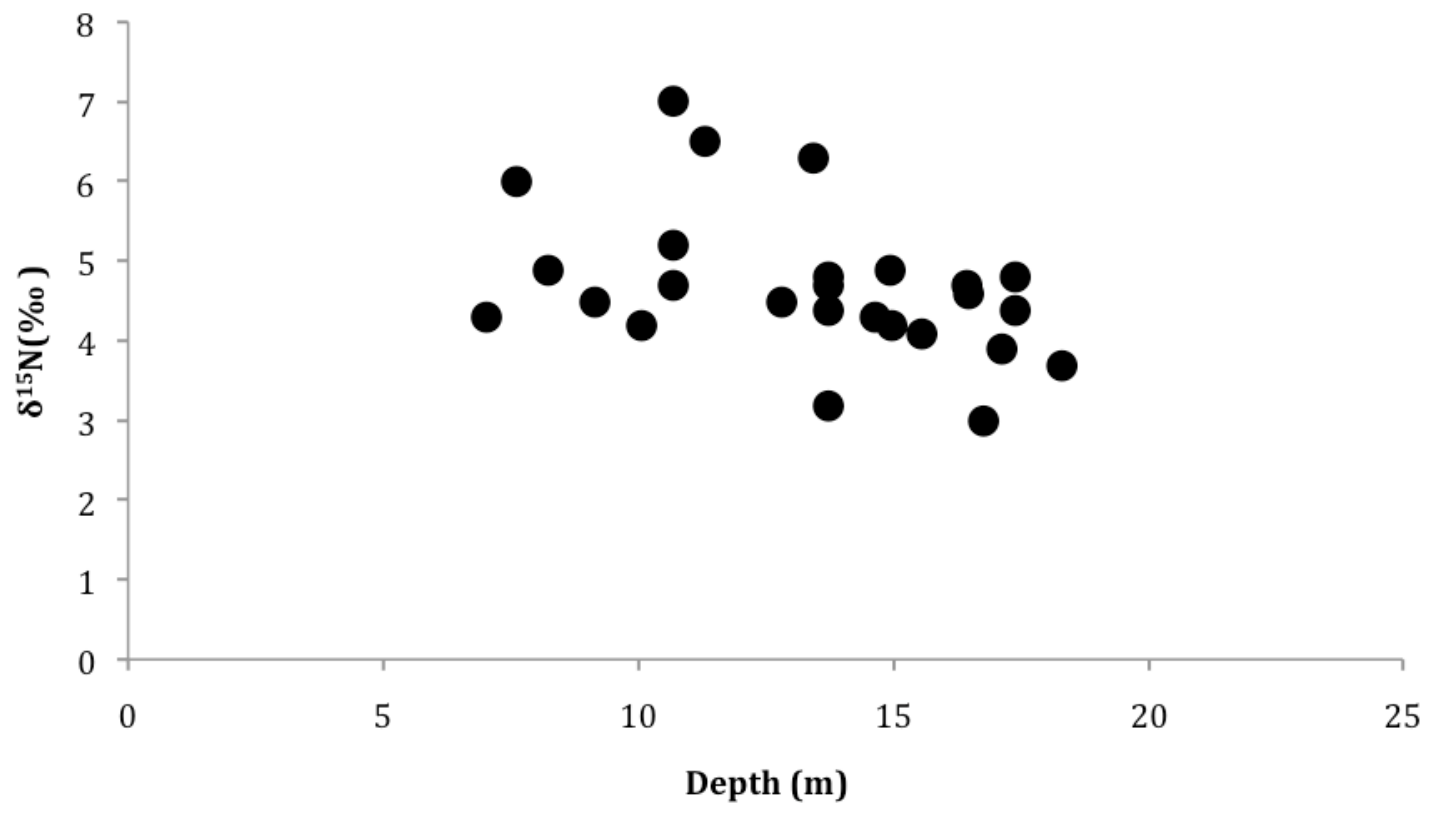

Figure 19. $\delta^{15} \mathrm{~N}$ values of Halimeda spp. with respect to depth 


\section{Biplot (axes F1 and F2: $\mathbf{3 6 . 3 6 \% )}$}

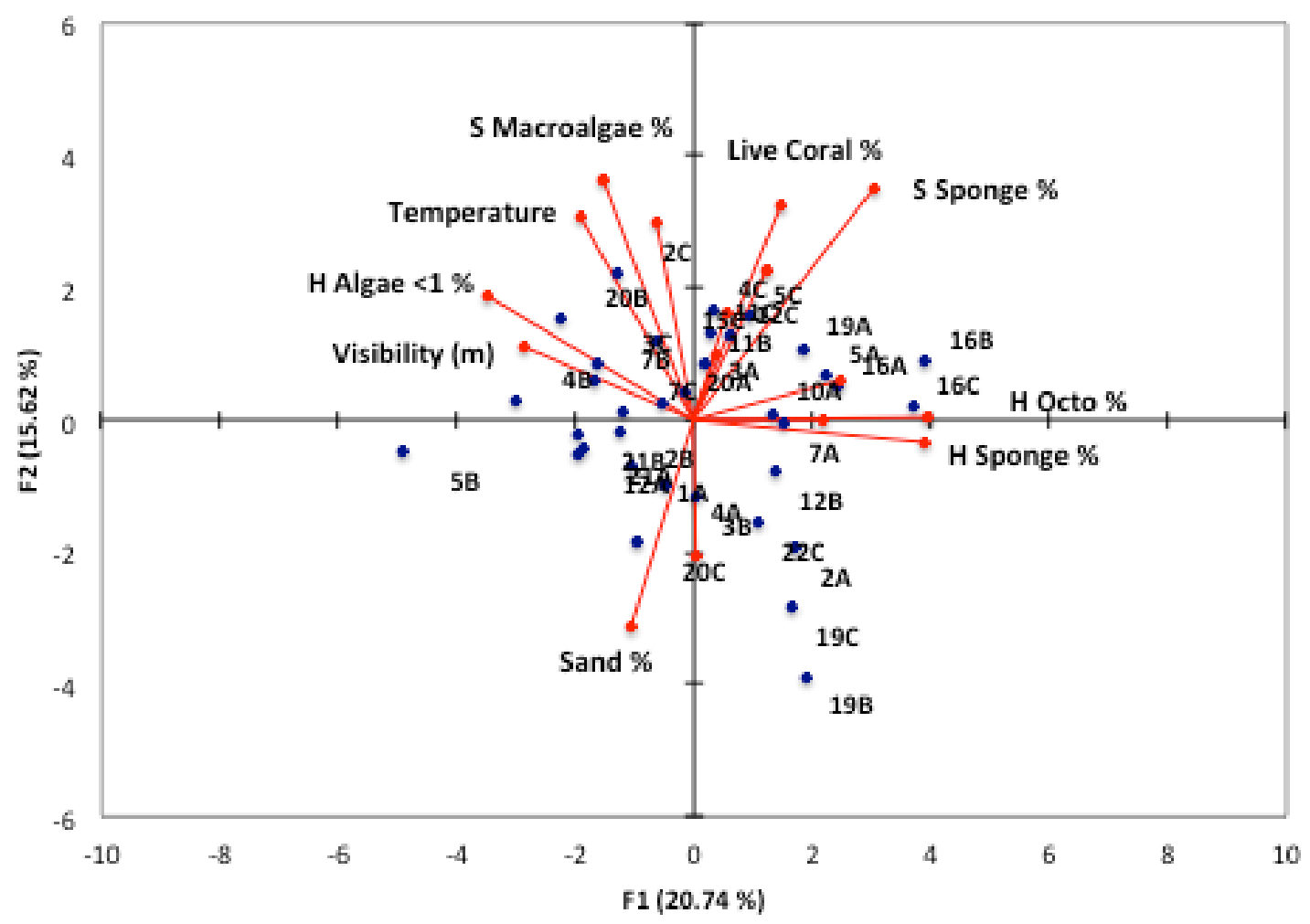

Figure 20. Principle component analysis for site variation with respect to benthic characteristics 


\section{WORKS CITED}

Adey, W. 1998. Review-coral reefs: algal structure and mediated ecosystems in shallow, turbulent, alkaline waters. Journal of Phycology 34(3): 393-406.

Anderson, W., Fourqurean, J. 2003. Intra- and interannual variability in seagrass carbon and nitrogen stable isotopes from south Florida, a preliminary study. Organic geochemistry 34: 185-194.

Anderson, W., Paul, V., Sneed, J. 2012. LBSP Project 32: Using Cyanobacteria and Macroalgae Stable Isotopes as Anthropogenic Point and Non-Point Source Nutrient Indicators. Florida Department of Environmental Protection. Miami, Fl. $28 \mathrm{p}$.

Baker, R., Hitling, A., Hayes, M. 2001. The changing health of coral reefs. Human and Ecological Risk Assessment: An International Journal 7(5): 1255-1270.

Banks, K., Riegel, M., Richards, V., Walker, B., Helmle, K., Jordan, L., Phipps, J., Shivji, M., Spieler, R., Dodge, R. 2008. The reef tract of Continental Southeast Florida (Miami-Dade, Broward and Palm Beach counties, USA). Coral Reefs of the USA 1: 175-220.

Barile, P. 2004. Evidence of anthropogenic nitrogen enrichment of the littoral waters of East Central Florida. Journal of Coastal Research 20(4): 1237-1245.

Bloetscher, F., Meeroff, D., Plummer, J. 2010. Evaluation of coastal ocean discharges and environmental impacts in South Florida. Environmental Practice. 12(4): 285-303.

Brenner, M., Whitmore, T., Curtis, J., Hodell, D., Schelske, C. 1999. Stable isotopes $\left(\delta^{13} \mathrm{C}\right.$ and $\left.\delta^{15} \mathrm{~N}\right)$ signatures of sedimented organic matter as indicators of historic lake trophic state. Journal of Paleolimnology 22: 205-221.

Bresett, M., Witherington, B., Herren, R., Bagley, D., Gorham, J., Traxler, S., Crady, C., Hardy, R. 2010. Size-class partitioning and herding in a foraging group of green turtles Chleonia mydas. Endangered species research 9: 105-116.

Briggs, K. and Richardson, M. 1997 Small-scale fluctuations in acoustic and physical properties in surficial carbonate sediment and their relationship to bioturbation. Geo-Marine Letters 17: 306-315. 
Candida, S. 2005. Tracing the influence of sewage nitrogen in coastal ecosystem using stable nitrogen isotopes. AMBIO: A Journal of the Human Environment 34(2): 145-150.

Carsey, T., Amornthammarong, N., Bishop, J., Bloetscher, F., Brown, C., Craynock, J., Cummings, S., Dammann, P., Featherstone, C., Goodwin, K., 2007. NOAA Data Report AOML-XX Boynton Inlet 48-hour Sampling Intensives, June and September, 2007.

Cocheret de la Moriniere, E., Pollux, B., Nagelkerken, I., Hemminga, M., Huiskes, A., van der Velde, G. 2003. Ontonogentic dietary changes of coral reef fishes in the mangrove-seagrass-reef continuum: stable isotopes and gut-content analysis. Marine Ecology Progress Series 246: 279-289.

Coolier, C., Ruzicka, R., Banks, K., Barbieri, L., Beil, J., Bingham, D., ..\&\&Warrick, D. 2008. The state of coral reef ecosystems of Southeast Florida. The state of coral reef ecosystems of the United States and Pacific Freely Associated states, 131159.

Costanzo, S. D, M. J. O’Donohue, W. C. Dennison, N. R. Loneragan, and M. Thomas. 2001. A new approach for detecting and mapping sewage impacts. Marine Pollution Bulletin 42: 149-156.

Côté, I., Precht, W., Aronson, R., Gardner, T. 2013. Is Jamaica a good model for understanding Caribbean coral reef dynamics? Marine pollution bulletin 76: 2831.

D'Angelo, C., Widenmann, J. 2014. Impacts of nutrient enrichment on coral reefs: new perspectives and implications for coastal management and reef survival. Current Opinion in Environmental Sustainability 7: 82-93.

Danovaro, R., Bongiorni, L., Corinaldesi, C., Giovannelli, D., Damiani, E., Astolfi, P., Greci, L., Pusceddu, A. 2008. Sunscreens cause coral bleaching by promoting viral infections. Environmental Health Perspectives 116(4): 441-447.

Diaz, M., Rützler, K. 2001. Sponges: an essential component of Caribbean coral reefs. Bulletin of marine science 69(2): 535-546.

Diaz-Pullido, G., McCook, L. 2005. Effects of nutrient enhancement on the fecundity of a coral reef macroalga. Journal of Experimental Marine Biology and Ecology 317: $13-24$. 
Edinger, E., Jompa, J., Limmon, G., Widjatmoko, W, Risk, M. 1998. Reef degradation and coral biodiversity in Indonesia: Effects of land-based pollution, destructive fishing practices, and changes over time. Marine Pollution Bulletin 36(8): 617630 .

Fanning, K., Carder, K., Betzer, P. 1982. Sediment resuspension by coastal waters: a potential mechanism for nutrient re-cycling on the ocean's margins. Deep Sea Research Part A. Oceanographic Research 29(8): 953-965.

Flore, C., Baker, D., Lesser, M. 2013. Nitrogen Biogeochemistry in the Caribbean Sponge, Xestospongia muta: A Source or Sink of Dissolved Inorganic Nitrogen? Plos One 8(8): e72961. doi:10.1371/journal.pone.0072961

Futch, J., Griffin, D., Banks, K., Lipp, E. 2011. Evaluation of sewage and fate of southeast Florida coastal reefs. Marine Pollution Bulletin 62: 2308-2316.

Gibson, P. 2011. Ecosystem impacts of carbon and nitrogen cycling by coral reef sponges. Chapel Hill.

Grace, R. Marine outfall construction: Background, Techniques, and Case studies. Virginia. American Society of Civil Engineers. 2009

Hitling, A., Currin, C., Kosaki, R. 2013. Evidence for benthic primary production support of an apex predator-dominated coral reef food web. Marine Biology 160: 1681-1695.

Hoch, M., Cifuentes, L., Coffin, R. 1995. Assessing geochemical and biological fate for point source loads of sewage-derived nitrogen and organic carbon in coastal waters of Southern Florida. Final Report to the USEPA.

Hoegh-Guldberg, O. 1999. Climate change, coral bleaching, and the future of the world's coral reefs. Marine Freshwater Research 50: 839-866

Hughes, T. 1994. Catastrophes, phase shifts, and large-scale degradation of a Carribean coral reef. Science 256(5178): 1547-1551.

Hurd, C., Harrison, P., Bischof, K., Lobban, C. Seaweed ecology and physiology. Cambridge University Press, 2014. Print.

Jackson, J., Donovan, M., Cramer, K., Lam, V. 2014. Status and trends of the Carribean Coral reefs: 1970-2012. Global Coral Reef Monitoring Network. IUCN. Gland, Switzerland. 
Jacob, U., Mintenbeck, K., Brey, T., Knust, B., Beyer, K. 2005. Stable isotope food web studies: a case for standardized sample treatment. Marine Ecology Progress Series 287: 251-253.

Knowlton, N., Jackson, J. 2008. Shifting baselines, local impacts, and Global change on coral reefs. PLoS Biol 6(2): e54. doi:10.1371/journal.pbio.0060054.

Kuramoto, T., Minagawa, M. Stable carbon and nitrogen isotopic characterization of organic matter in a mangrove ecosystem of southwester coastal of Thailand. Journal of Oceanography 57: 421-431.

Kurten, B., Al-Aidaroos, A., Struck, U., Khomayis, H., Gharbawi, W., Sommer, U. 2014. Influence of environmental gradients on $\mathrm{C}$ and $\mathrm{N}$ stable isotope ratios in coral reef biota of the Red Sea, Saudi Arabia. Journal of Sea Research 85: 379-394.

Lamb, K., Swart, P., Altabet, M. 2012 Nitrogen and carbon isotopic systematics of the Florida Reef Tract. Bulletin of Marine Science 88(1): 1-28.

Leichter, J., Paytan A., Wanzel S., Hanson. K. 2007. Nitrogen and oxygen isotopic signatures of subsurface nitrate seaward of the Florid Keys reef tract. Limnology Ocean 52: 1258-1267.

Lapointe, B., Barile, P., Matzie, W. 2004. Anthropogenic nutrient enrichment of seagrass and coral reef communities in the lower Florida Keys: discrimination of local vs. regional nitrogen sources. Journal of Experimental Marine Biology and Ecology 308: 23-58.

LaPointe, B., Barile, P., Littler, M., Littler, D. 2005. Macroalgal blooms on southeast Florida coral reefs II. Cross-shelf discrimination of nitrogen sources indicates widespread assimilation of sewage nitrogen. Harmful Algae 4: 1106-1122.

Lin, P., \& Sasso, R. 2001. Influence of nearshore hard bottom on regional sediment transport. Coastal Engineering Proceedings 1(25).

Lirman, D., Biber, P. 2000. Seasonal dynamics of macroalgal communities of the Northern Florida Reef Tract. Botanica Marina 43: 305-314.

McClelland, J., and Valiela, I. 1998. Changes in food web structure under the influence of increased anthropogenic nitrogen inputs to estuaries. Marine Ecology Progress Series 168: 259-271. 
McCook, L. 1999. Macroalgae, nutrients and phase shifts on coral reefs: scientific issues and management consequences for the Great Barrier Reefs. Coral reefs 18: 357367.

McCook, L. 2001 Competition between coral and algal turfs along a gradient of terrestrial influence in the near shore central Great Barrier Reef. Coral Reefs, 19: 419-425.

McCook, L., Jompa, J., Diaz-Pullido, G.2001. Competition between corals and algae on coral reefs: A review of evidence and mechanisms. Coral Reefs 18: 1-11.

McManus, J., Polsenberg, J. 2004. Coral-algal phase shifts on coral reefs: ecological and environmental aspects. Progress in Oceanography 60: 263-279.

Nelson, W. 2009. Calcified macroalgae - critical to coastal ecosystems and vulnerable to change: a review. Marine and Freshwater Research 60: 787-801.

Nielson, S. 2011. Sediment dynamics of a shallow hypereutrophic lake: Lake Jesup, Florida, USA. FIU Electronic Theses and Dissertations. Paper 511.

Paul, V., Fenical, W. 1983. Isolation of halimedatrial: chemical defense adaptation in the calcareous reef-building alga Halimeda. Science 221(4612): 747-749

Peterson, B. and Fry, B. 1987. Stable isotopes in ecosystem studies. Annual review of Ecology and Systematics 18: 293-320.

Phillips, R. 1959. Notes on the marina flora of the Marquesas Keys, Florida. Florida Academy of Sciences 22(3): 155-162.

Quinn, N. 2005. Assessing the Potential for Natural Recovery and Coral Restoration Techniques for Enhancing Coral Habitat in Jamaica. Ocean 3: 2752-2759.

Risk, B., Sherwood, O., Bedford, B. 2009. The use of d15N in assessing sewage stress on coral reefs. Marine Pollution Bulletin 58: 793-802.

Savage, C. and Elmgren, R. 2004. Macroalgal (Fucus vesiculosus) $\delta 15 \mathrm{~N}$ values trace decrease in sewage influence. Ecological Applications, 14(2): 517- 526.

Smith, B., Epstein, S. 1971. Two categories of ${ }^{13} \mathrm{C} /{ }^{12} \mathrm{C}$ ratios for higher plants. Plant Physiology 47: 380-384.

Solorzano, L and Sharp, J.H., 1980. Determination of Total Dissolved Phosphorus and Particulate Phosphorus in Natural Waters. Limnology and Oceanography 25(4): 754- 758. 
Steneck, R., Arnold, S., Debey, H. 2011. Status and trends of Bonaire's coral reefs 2011 cause for grave concerns. University of Maine, School of Marine Sciences, Darling Marine Center, Walpole, ME 04573.

Swart, P., Saied, A., Lamb., K. Temporal and spatial variation in the $\delta^{15} \mathrm{~N}$ and $\delta^{13} \mathrm{C}$ of coral tissue and zooxanthellae in Montastraea faveolata collected from the Florida reef tract. Limnology and Oceanography 50(4): 1049-1058.

Swart, P. 2010. Nitrogen isotope studies of pollution in the coastal waters of Florida: final report. Stable Isotope Laboratory, Division of Marine Geology and Geophysics, Rosenstiel School of Marine and Atmospheric Science, University of Miami, Miami, FL, 23 pp.

Swart, P., Anderson, W., Altabet, M., Drayer, C., Bellmund, S. 2013. Sources of dissolved inorganic nitrogen in a coastal lagoon adjacent to a major metropolitan area, Miami, Florida (USA). Applied Geochemistry 38: 134-146.

Sweeney, R. and Kaplan, I. 1980. Tracing flocculent industrial and domestic sewage transport on San Pedro Shelf, southern California, by nitrogen and sulfur isotope ratios. Marine Environmental Research 3: 215-224.

Tichenor, E. 2006. Examination of effluent plume behavior Delray Beach, Florida, ocean outfall. Palm Beach County Reef Rescue, Boynton Beach, Beach, FL. Available at http:/www.reef-rescue.org/research/DelrayPlumeBehaviorLoR.pdf accessed July 23, 2013.

Tucker, J., Sheats, N., Giblin, A., Hopkinson C., Montoya, J. 1999. Using stable isotopes to trace sewage-derived material through Boston Harbor and Massachusetts Bay. Marine Environmental Research 48: 353-375.

Umezawa, Y., Miyajima, T., Yamamuro, M., Kayanne, H. 2002. Fine-scale mapping of land direved nitrogen in coral reefs by $\delta^{15} \mathrm{~N}$ in macroalgae. Limnol. Oceanogr. 47(5): 1405-1416.

United States Environmental Protection Agency. 2002. Technical program overview: underground injection control regulations, revised July 2001. Office of Water 4606 EPA 816-R-02-025, USEPA, Washington, DC

United States Environmental Protection Agency. 2006. Ocean Outfalls. US Environmental Protection Agency, 1-54. (http://www.epa.gov/region54/water/uic/downloads/ra/06-ocean.pdf). 
Vizzini, S., Mazzola, A. 2006. The effects of anthropogenic organic matter inputs on stable carbon and nitrogen isotopes in organism from different trophic levels in a southern Mediterranean coastal area. Science of the Total Environment 368: 723-731.

Ward-Paige, C., Risk, M., Sherwood, O., Jaap, W. 2005. Clionid sponge surveys on the Florida Reef Tract suggesting land-based nutrient inputs. Marine pollution bulletin 51: 570-579.

Washnicka, A., Collins, L., Gaiser, E. 2013. Response of diatom assemblages to 130 years of environmental change in Florida Bay (USA). Journal of Paleoliminology 49: 83-101.

Weinberg, H., Singer, P., Cook, S. 2002. Assessment of trace elements concentrations in municipal wastewater treatment plant discharges in North Carolina. UNC-WRRI2002-337. Water Resources Research Institute, University of North Carolina, Raleigh, 124 pp.

Yniguez, A. 2007. Spatial dynamic in the growth and spread of halimeda and dictyota in Florida reefs: A simulation modeling approach. Open Access Dissertations. Paper 62. 